\title{
Assessing the environmental sustainability of electricity generation in Chile
}

DOI:

10.1016/j.scitotenv.2018.04.346

\section{Document Version}

Accepted author manuscript

Link to publication record in Manchester Research Explorer

\section{Citation for published version (APA):}

Gaete Morales, C., Gallego Schmid, A., Stamford, L., \& Azapagic, A. (2018). Assessing the environmental sustainability of electricity generation in Chile. Science of the Total Environment, 636, 1155-1170. https://doi.org/10.1016/j.scitotenv.2018.04.346

\section{Published in:}

Science of the Total Environment

\section{Citing this paper}

Please note that where the full-text provided on Manchester Research Explorer is the Author Accepted Manuscript or Proof version this may differ from the final Published version. If citing, it is advised that you check and use the publisher's definitive version.

\section{General rights}

Copyright and moral rights for the publications made accessible in the Research Explorer are retained by the authors and/or other copyright owners and it is a condition of accessing publications that users recognise and abide by the legal requirements associated with these rights.

\section{Takedown policy}

If you believe that this document breaches copyright please refer to the University of Manchester's Takedown Procedures [http://man.ac.uk/04Y6Bo] or contact uml.scholarlycommunications@manchester.ac.uk providing relevant details, so we can investigate your claim.

\section{OPEN ACCESS}




\title{
Assessing the environmental sustainability of electricity generation in Chile
}

\author{
Carlos Gaete-Morales, Alejandro Gallego-Schmid, Laurence Stamford and Adisa Azapagic* \\ Sustainable Industrial Systems, School of Chemical Engineering and Analytical Science, University \\ of Manchester, C16, the Mill, Sackville Street, Manchester M13 9PL, UK. \\ *Corresponding author: adisa.azapagic@ manchester.ac.uk
}

\begin{abstract}
Around $40 \%$ of electricity in Chile is supplied by renewables and the rest by fossil fuels. Despite the growing electricity demand in the country, its environmental impacts are as yet unknown. To address this gap, the current study presents the first comprehensive assessment of the life cycle environmental sustainability of electricity generation in Chile. Both the individual sources and the electricity mix over the past 10 years are considered. The following sources present in the electricity mix are evaluated: coal, oil, natural gas, biogas, biomass, wind, solar photovoltaics (PV) and hydropower. In total, 10 electricity technologies and 174 power plants installed across the country have been considered. Eleven environmental impacts have been estimated, including global warming, human toxicity, ecotoxicities, as well as resource and ozone layer depletion. The results reveal that hydropower is environmentally the most sustainable option across the impacts, followed by onshore wind and biogas. Electricity from natural gas has 10\%-84\% lower impacts than biomass for seven categories. It is also 13\%-98\% better than solar PV for six impacts and 17\%-66\% than wind for four categories. Solar PV has the highest abiotic depletion potential due to the use of scarce elements in the manufacture of panels. While electricity generation has grown by $44 \%$ in the past 10 years, all the impacts except ozone layer depletion have increased by 1.6-2.7 times. In the short term, environmental regulations should be tightened to improve the emissions control from coal and biomass plants. In the medium term, the contribution of renewables should be ramped up, primarily increasing the hydro, wind and biogas capacity. Coal and oil should be phased out, using natural gas as a transitional fuel to help the stability of the grid with the increasing contribution of intermittent renewables.
\end{abstract}

Keywords: fossil fuels; renewable technologies; environmental sustainability; climate change; resource depletion; LCA.

\section{Introduction}

From the 1970 s to the '90s, the electricity mix in Chile was mainly shaped by hydropower, with a lower contribution from fossil fuel power plants (Figure 1). However, high electricity demand, public objections to new hydropower projects, hydrological variability and the lack of planning in the sector have resulted in the current electricity mix being dominated by fossil fuels [1]. In 2014, 174 power plants were in operation in Chile, with fossil fuel technologies contributing $60 \%$ to the total electricity supply, hydropower $34 \%$ and other renewable options $6 \%$ (Table 1) [2]. Electricity from coal is generated using pulverised coal which provides $41 \%$ of total electricity. For gas and oil, both combined and open cycle plants are used $(16.6 \%$ and $1.2 \%$ of the total generation, respectively). Oil power is generated by diesel engines, which contribute only $0.5 \%$ to the total due to their high costs [3]. Biomass electricity is mainly supplied by combined heat and power (CHP) plants $(3.5 \%$ of the total), with the majority produced by the pulp and paper industry. Hydroelectricity is produced using reservoirs and run-of-river systems, with contributions of $19 \%$ and $15 \%$, respectively. Finally, solar photovoltaics (PV) and wind contribute only $0.7 \%$ and $2 \%$ to the generation mix. 


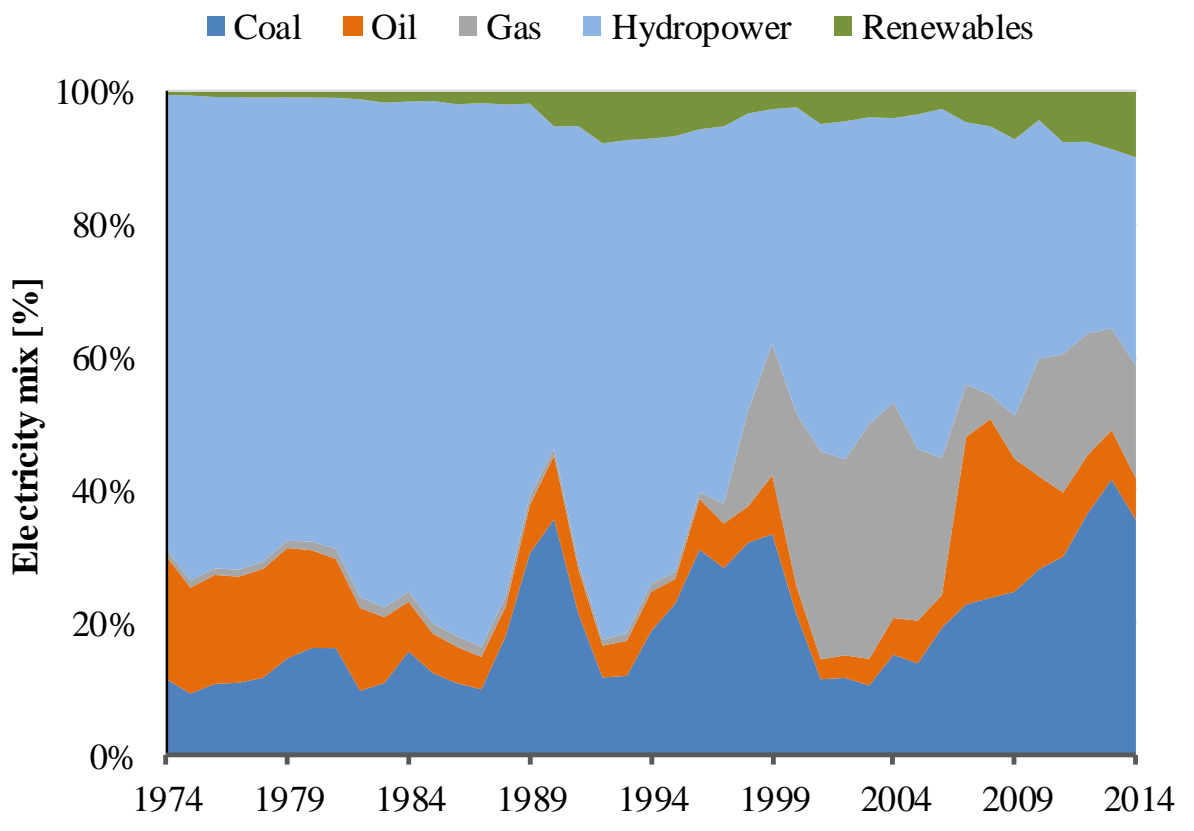

Figure 1: Historical electricity mix in Chile between 1974 and 2014 [2].

Table 1. Electricity generation in Chile in 2014 by source and technology [2].

\begin{tabular}{|c|c|c|c|c|c|c|c|c|c|}
\hline \multicolumn{9}{|c|}{ Electricity generation by source $(\mathbf{G W h})$} & \multirow{2}{*}{$\begin{array}{c}\text { Contribution } \\
(\%)\end{array}$} \\
\hline Technology & Coal & Natural gas & $\begin{array}{c}\text { Oil } \\
\text { (diesel) }\end{array}$ & $\begin{array}{l}\text { Biomass } \\
\& \text { biogas }\end{array}$ & Hydro & Wind & Solar & Total & \\
\hline Pulverised coal & 28,892 & & & & & & & 28,892 & 41.4 \\
\hline Combined cycle & & 9,554 & 2,002 & & & & & 11,556 & 16.6 \\
\hline Open cycle & & 443 & 377 & & & & & 820 & 1.2 \\
\hline Diesel engine & & & 366 & & & & & 366 & 0.5 \\
\hline Combined heat and power & & & & 2,427 & & & & 2,427 & 3.5 \\
\hline Biogas engine & & & & 283 & & & & 283 & 0.4 \\
\hline Reservoir & & & & & 13,092 & & & 13,092 & 18.8 \\
\hline Run-of-river & & & & & 10,450 & & & 10,450 & 15.0 \\
\hline Onshore turbine & & & & & & 1,425 & & 1,425 & 2.0 \\
\hline Photovoltaics & & & & & & & 464 & 464 & 0.7 \\
\hline Total & 28,892 & 9,997 & 2,745 & 2,710 & 23,542 & 1,425 & 464 & 69,775 & 100 \\
\hline
\end{tabular}

The electricity sector in Chile faces many challenges. Electricity generation is the main contributor to greenhouse gas (GHG) emissions in the country [4]. Energy security is low due to a lack of indigenous fossil fuels [5] and the high cost of electricity has hampered economic growth [6]. The electricity sector also contributes the most to social and environmental conflicts (37\%) in the country [7]. Even though hydropower has a significant generation potential (Table 2) and is the most economical option with low environmental impacts, its development has been slow. This is due to its effects on land use, related social implications and public opposition which have discouraged investment in this technology [8]. These problems suggest the need for identifying sustainable electricity options to help improve the sustainability of the sector in the country.

The Chilean government has started stimulating the diversification of electricity supply with the deployment of renewable and low-carbon technologies, while at the same time trying to reduce electricity prices [1]. Owing to its geographical characteristics and variety of climates, Chile has abundant renewable resources, such as solar, wind, geothermal, hydro and biomass [9, 10]. As 
illustrated in Table 2, the solar power potential is outstanding, with an estimated 100-548 GW for concentrating solar power (CSP) and more than 1,263 GW for solar photovoltaics (PV). This huge potential is due to the vast areas with the highest solar irradiation in the world, with capacity factors of up to $40 \%$ for solar PV systems [11]. Similarly, wind power potential is also significant, with estimated values of 37-40 GW and a capacity factor of 34\% [11]. Geothermal, hydro and biomass potentials are also significant, with an average of $15 \mathrm{GW}$ each.

Table 2. Estimated potential for renewable power and capacity factors in Chile [9, 11].

\begin{tabular}{lcc}
\hline Technology & Potential $(\mathbf{G W})$ & Capacity factor \\
\hline Solar photovoltaics & $1,263^{\mathrm{a}}$ & $33 \%$ \\
Solar concentrating solar power & $100-548$ & $52 \%$ \\
Wind & $37-40$ & $34 \%$ \\
Hydropower & $12-20$ & $63 \%$ \\
Geothermal & 16 & \\
Biomass & 14 & \\
Total & $\mathbf{1 , 8 6 4}$ & \\
\hline
\end{tabular}

a One axis tracking.

In an attempt to improve the sustainability of the national electricity supply, the Chilean government defined environmental, economic and social actions for the sector in its Energy Policy $2050[1,12,13]$. In spite of that, there are still no comprehensive studies in Chile of the sustainability of the current electricity system. This paper aims to address this gap by establishing a baseline for the environmental sustainability of electricity supply in Chile, to assist the government and the industry in identifying the hotspots and how to address them. Life cycle assessment (LCA) has been used for these purposes, to enable consideration of whole electricity supply chains.

LCA has been used previously to study the environmental impacts of electricity generation in other countries, but there is no comprehensive LCA study for Chile. Examples of studies elsewhere including Mexico [14], Nigeria [15], Turkey [16], United Kingdom [17], Portugal [18] and Brazil [19]. Several LCA databases (e.g. CCaLC [20], Ecoinvent [21] and Gabi [22]) also provide life cycle inventories (LCI) for electricity systems in different countries. However, only the Ecoinvent database [23] has recently included the LCI of electricity generation in Chile. These data have been developed from European LCI datasets, simply accounting for the Chilean electricity mix. This is inadequate as it fails to consider country-specific parameters, such as power plant efficiencies, capacity factors, types of technology, heating values of fuels, actual emissions from power plants, end-of-life waste management, etc. This study considers all of these parameters (around 140), for all 174 plants. In addition, it also follows the temporal evolution of the impacts over the period of 10 years (2004-2014). The impacts are estimated for each technology present in the Chilean electricity mix to allow their comparison and identification of hotspots. This is followed by the evaluation of the environmental sustainability of the electricity mix, both for the current situation and over the past decade. The results are used to make suggestions for improving the environmental sustainability of electricity supply in Chile. As far as we know, this is the first such study of the life cycle environmental sustainability of electricity in Chile.

\section{Methods}

The environmental sustainability of the electricity mix has been assessed using attributional LCA and following the ISO 14040 [24] and ISO 14044 [25] standards. The goal and scope of the study are defined below, with the inventory data detailed in section 2.2 and the impact assessment method in section 2.3 . 


\subsection{Goal and scope definition}

The main goals of the study are:

i. to estimate and compare the environmental impacts of electricity sources and technologies currently present in the electricity mix;

ii. to estimate the impacts of the current electricity mix;

iii. to map the temporal evolution of impacts from electricity over the past 10 years; and

iv. to identify environmental hotspots and make recommendations for future improvements.

Consequently, the following functional units have been considered:

- $1 \mathrm{kWh}$ of electricity generated by each source and technology (study goals i and iv);

- $1 \mathrm{kWh}$ of electricity generated by the Chilean electricity mix (goals ii-iv); and

- annual electricity generation over the past 10 years (goal iii).

The scope of the study is from 'cradle to gate' as shown in Figure 2. The following life cycle stages have been considered for each source and technology: fuel production, transport and processing (where relevant), power plant construction, operation and decommissioning. Transmission, distribution and use of electricity are excluded as the focus is on electricity generation.

As indicated in Table 1, the following electricity technologies have been considered: pulverised coal, open and combined cycle turbines (oil and gas), diesel engine (oil), gas engine (biogas), CHP (biomass), reservoir and run-of-river (hydropower), onshore wind and multi-crystalline solar PV.

2.2. Inventory data

All 174 plants connected to the two major electric interconnected systems in Chile - Central Interconnected System (SIC) and Interconnected System of Norte Grande (SING) - have been considered. These plants generate $98 \%$ of the total electricity supply in the country.

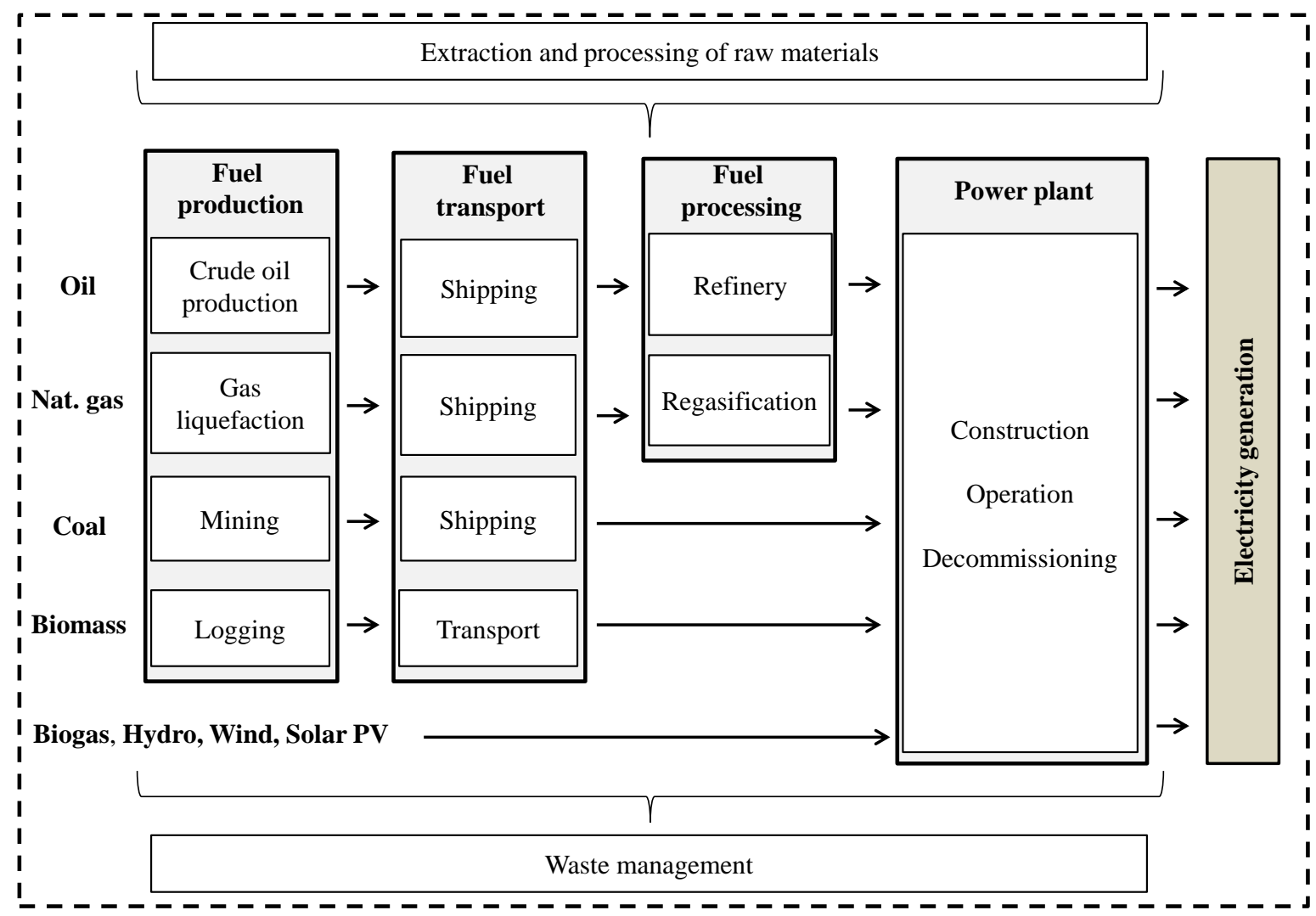

Figure 2. Scope of the study and the life cycle stages for different electricity sources. 
Primary data have been collected from the National Energy Commission (CNE) [2] and Load Economic Dispatch Centre of the Central Interconnected System (CDEC-SIC) [26]). Further academic literature and institutional reports have also been considered, as detailed further below. The year 2014 is taken as the base year as the most recent and comprehensive data were available for that year during the course of this study. The Ecoinvent 2.2 database [21] has been used for the background data. The following subsections detail the LCI for each technology, together with the main assumptions.

\subsubsection{Fossil fuels}

An overview of the inventory data and assumptions for electricity from fossil fuels can be found in Table 3-Table 5. Hourly data for air emissions have been considered for each power plant, sourced from the Chilean Department for the Environment [27]. As mentioned earlier, fossil-based electricity supplies $60 \%$ of electricity in Chile, $68 \%$ of which is from coal $(41 \%$ of the whole electricity mix). There are 18 coal power plants in operation, most of which use hard coal; the exception are two installations that are partially fed with petroleum coke (petcoke). Two types of technologies are used for coal power generation: pulverised coal (PC) and circulating fluidised bed (CFB). However, only $8 \%$ of the coal power installed capacity is CFB. Therefore, for both simplicity and lack of data on CFB, only PC has been considered, assuming that it supplies $100 \%$ of electricity from coal.

Table 3. Inventory data for electricity generation from coal in 2014

\begin{tabular}{|c|c|}
\hline Life cycle stage & Data \\
\hline Fuel supply & $\begin{array}{l}\text { Annual consumption: } 11.2 \text { million tonnes (95\% coal, } 5 \% \text { petcoke) } \\
\text { Mass contribution and calorific value (higher heating value): } \\
\text { Australian coal: } 8 \%, 27 \mathrm{MJ} / \mathrm{kg} \\
\text { Colombian coal: } 54 \%, 26.8 \mathrm{MJ} / \mathrm{kg} \\
\text { Chilean coal: } 10 \%, 18.9 \mathrm{MJ} / \mathrm{kg} \\
\text { USA coal: } 23 \%, 26.0 \mathrm{MJ} / \mathrm{kg} \\
\text { Chilean petcoke: } 2 \%, 32.5 \mathrm{MJ} / \mathrm{kg} \\
\text { USA petcoke: } 3 \%, 32.5 \mathrm{MJ} / \mathrm{kg} \\
\text { Average sulphur content (weighted to account for the above mass contributions): } 0.7 \%\end{array}$ \\
\hline $\begin{array}{l}\text { Transport } \\
\text { (shipping) }\end{array}$ & $\begin{array}{l}\text { Australia: } 11,959 \mathrm{~km} \\
\text { Chilean coal mines: } 3,220 \mathrm{~km} \\
\text { Colombia: } 4,585 \mathrm{~km} \\
\text { USA: } 8,785 \mathrm{~km}\end{array}$ \\
\hline $\begin{array}{l}\text { Power plant } \\
\text { (pulverised coal) }\end{array}$ & $\begin{array}{l}\text { Installed capacity: } 4,167 \mathrm{MW}_{\mathrm{e}} \\
\text { Electricity generation: } 28,892 \mathrm{GWh} / \mathrm{yr} \\
\text { Efficiency: } 36 \% \\
\text { Capacity factor: } 81 \% \\
\text { Lifespan: } 38 \mathrm{yr} \\
\text { Ash disposal: } 4 \mathrm{~g} \text { of ash waste/MJ fuel burned } \\
\text { Direct emissions (after emission control) } \\
\quad \mathrm{CO}_{2}: 97.5 \mathrm{~g} / \mathrm{MJ} \\
\mathrm{NOx}^{\mathrm{a}}: 170 \mathrm{mg} / \mathrm{MJ} \\
\mathrm{SO}_{2}: 340 \mathrm{mg} / \mathrm{MJ} \\
\mathrm{Particles} 6.7 \mathrm{mg} / \mathrm{MJ}\end{array}$ \\
\hline
\end{tabular}

As shown in Table 5 and Table 4, natural gas and oil are used in combined and open cycle plants. The installed capacity of combined cycle (CC) power plants is $3,345 \mathrm{MW}_{\mathrm{e}}$. In $2014,83 \%$ of the electricity was produced from natural gas and $17 \%$ from diesel. There are 31 plants with open cycle (OC) gas turbines and a total installed capacity of $2,085 \mathrm{MW}_{\mathrm{e}}$. They generated $820 \mathrm{GWh}$ of electricity in 2014, of which $443 \mathrm{GWh}(54 \%)$ was from natural gas and $377 \mathrm{GWh}$ (46\%) from oil. Finally, there are 35 diesel engine power plants that supplied $366 \mathrm{GWh}$ of electricity in the same year. All natural gas is shipped in liquefied form and regasified in Chile. 
Table 4. Inventory data for electricity generation from oil (diesel) in 2014.

\begin{tabular}{|c|c|c|c|c|}
\hline Life cycle stage & \multicolumn{4}{|l|}{ Data } \\
\hline \multirow[t]{11}{*}{ Fuel supply } & \multicolumn{4}{|c|}{ Crude oil mix to refinery: } \\
\hline & \multicolumn{4}{|c|}{ Latin-American countries: $84 \%$} \\
\hline & \multicolumn{4}{|c|}{ UK: $16 \%$} \\
\hline & \multicolumn{4}{|c|}{ Diesel mix: } \\
\hline & \multicolumn{4}{|c|}{ Chile (from refinery): $43 \%$} \\
\hline & \multicolumn{4}{|c|}{ USA: $57 \%$} \\
\hline & \multicolumn{4}{|c|}{ Refinery: } \\
\hline & \multicolumn{4}{|c|}{ Crude processing capacity: 11 million $\mathrm{m}^{3}$ (three refineries) } \\
\hline & \multicolumn{4}{|c|}{ Annual diesel consumption: 523 thousand tonnes } \\
\hline & \multicolumn{4}{|c|}{ Calorific value (High heating value): $45.6 \mathrm{MJ} / \mathrm{kg}$} \\
\hline & \multicolumn{4}{|c|}{ Average sulphur content (weighted to account the above imports): $0.4 \%$} \\
\hline \multirow{4}{*}{$\begin{array}{l}\text { Transport } \\
\text { (shipping) }\end{array}$} & \multicolumn{4}{|c|}{ Diesel import from the USA: $8,785 \mathrm{~km}$} \\
\hline & \multicolumn{4}{|c|}{ Crude oil import from Latin-American countries: 5,204 km } \\
\hline & \multicolumn{4}{|c|}{ Crude oil import from the UK: $11,112 \mathrm{~km}$} \\
\hline & \multicolumn{4}{|c|}{ Diesel distribution from refinery to power plants: $664 \mathrm{~km}$} \\
\hline \multirow[t]{10}{*}{ Power plant } & & Combined cycle & Open cycle & Diesel engine \\
\hline & Installed capacity & $1,005 \mathrm{MW}_{\mathrm{e}}$ & $1,600 \mathrm{MW}_{\mathrm{e}}$ & $810 \mathrm{MW}_{\mathrm{e}}$ \\
\hline & Electricity generation & $2,002 \mathrm{GWh} / \mathrm{yr}$ & $377 \mathrm{GWh} / \mathrm{yr}$ & $366 \mathrm{GWh} / \mathrm{yr}$ \\
\hline & Efficiency & $44 \%$ & $34 \%$ & $36 \%$ \\
\hline & Capacity factor & $22 \%$ & $3 \%$ & $5 \%$ \\
\hline & Lifespan & 45 years & 45 years & 45 years \\
\hline & \multicolumn{4}{|c|}{ Direct emissions (after emission control) $^{\mathrm{a}}$} \\
\hline & $\mathrm{CO}_{2}$ & $88.9 \mathrm{~g} / \mathrm{MJ}$ & $80.5 \mathrm{~g} / \mathrm{MJ}$ & $75.9 \mathrm{~g} / \mathrm{MJ}$ \\
\hline & $\mathrm{NO}_{\mathrm{x}}$ & $295 \mathrm{mg} / \mathrm{MJ}$ & $265 \mathrm{mg} / \mathrm{MJ}$ & $829 \mathrm{mg} / \mathrm{MJ}$ \\
\hline & $\mathrm{SO}_{2}$ & $185 \mathrm{mg} / \mathrm{MJ}$ & $474 \mathrm{mg} / \mathrm{MJ}$ & $192 \mathrm{mg} / \mathrm{MJ}$ \\
\hline
\end{tabular}

${ }^{a}$ Mean values of hourly emissions averaged over a year and expressed per unit of higher heating value of fuel.

Table 5. Inventory data of electricity generation from natural gas in 2014

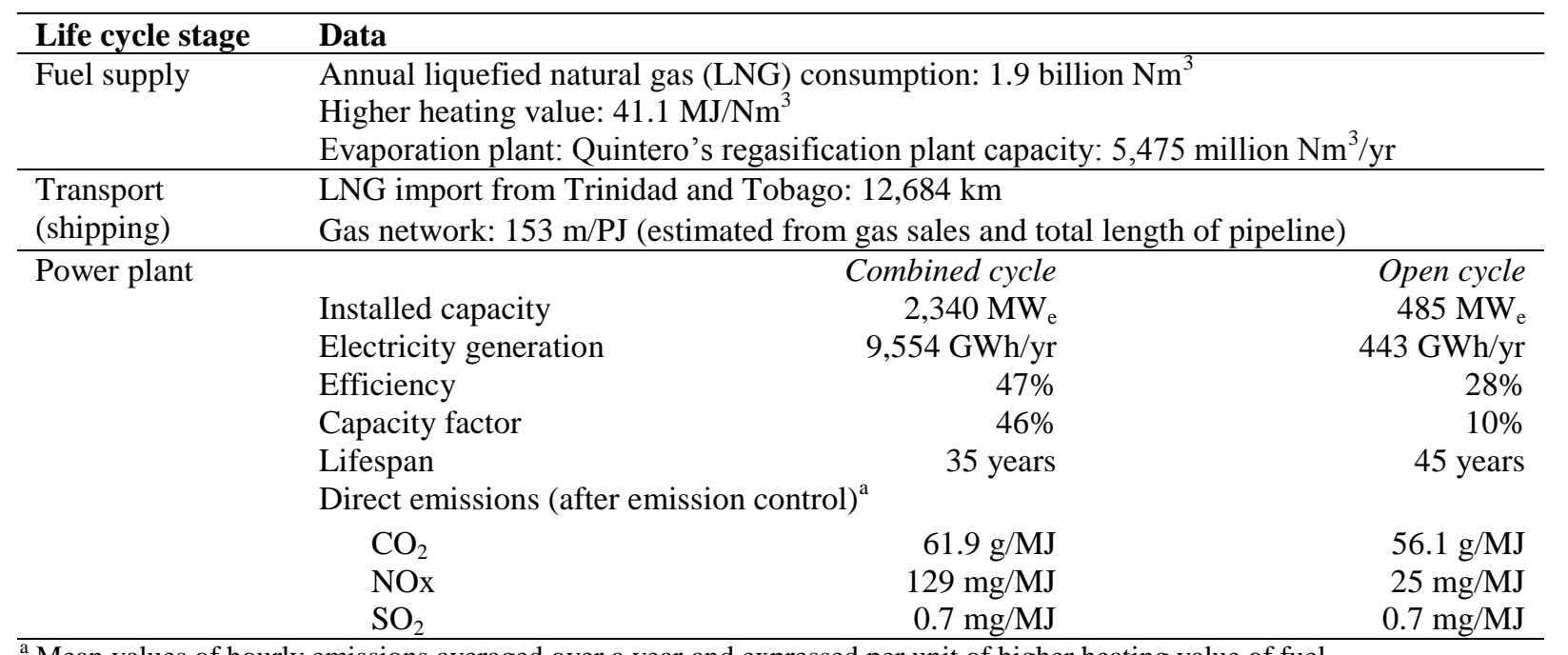

${ }^{a}$ Mean values of hourly emissions averaged over a year and expressed per unit of higher heating value of fuel.

\subsubsection{Renewables}

\subsubsection{Electricity from biogas}

There are eight biogas plants in Chile with an installed capacity of $42 \mathrm{MW}_{\mathrm{e}}$ (Table 6 and Table S1 in the Supporting Information (SI)). They contributed only $0.4 \%$ to the total electricity supply in 2014 (Table 1). The majority (83\%) of biogas electricity is produced by two landfills located in Santiago de Chile: Loma Los Colorados and Santa Marta. A further 15\% is produced by anaerobic digestion of sewage sludge from the wastewater treatment plant of El Tebal and the remaining 3\% is from manure and organic waste. Biogas engine is the main technology used for co-generation of 
electricity and heat $[28,29]$. The latter is used for heating the anaerobic digesters but it is not utilised in landfill biogas generation.

Electricity from manure and organic waste is not considered due to the low contribution (3\%) and a lack of specific data. Furthermore, production of biogas in landfills is assumed 'burden free' as it is produced from landfilled waste through its natural decomposition. Therefore, only the burdens associated with the production of biogas by anaerobic digestion of sewage sludge are considered for the biogas mix. Exergy allocation has been applied between electricity and heat, assigning $60 \%$ of the burdens to the former [30]. The emissions of $\mathrm{NO}_{\mathrm{x}}$ and $\mathrm{SO}_{2}$ from biogas production have been sourced from the GEMIS database [31]. The infrastructure-related impacts of the biogas plants have been taken into account but had to be scaled up (see section 2.2.3) because the size of the cogeneration plant in Ecoinvent $\left(160 \mathrm{~kW}_{\mathrm{e}}\right)$ is lower than the average plant in Chile $\left(1 \mathrm{MW}_{\mathrm{e}}\right)$.

Table 6. Inventory data for electricity generation from biogas and biomass in 2014.

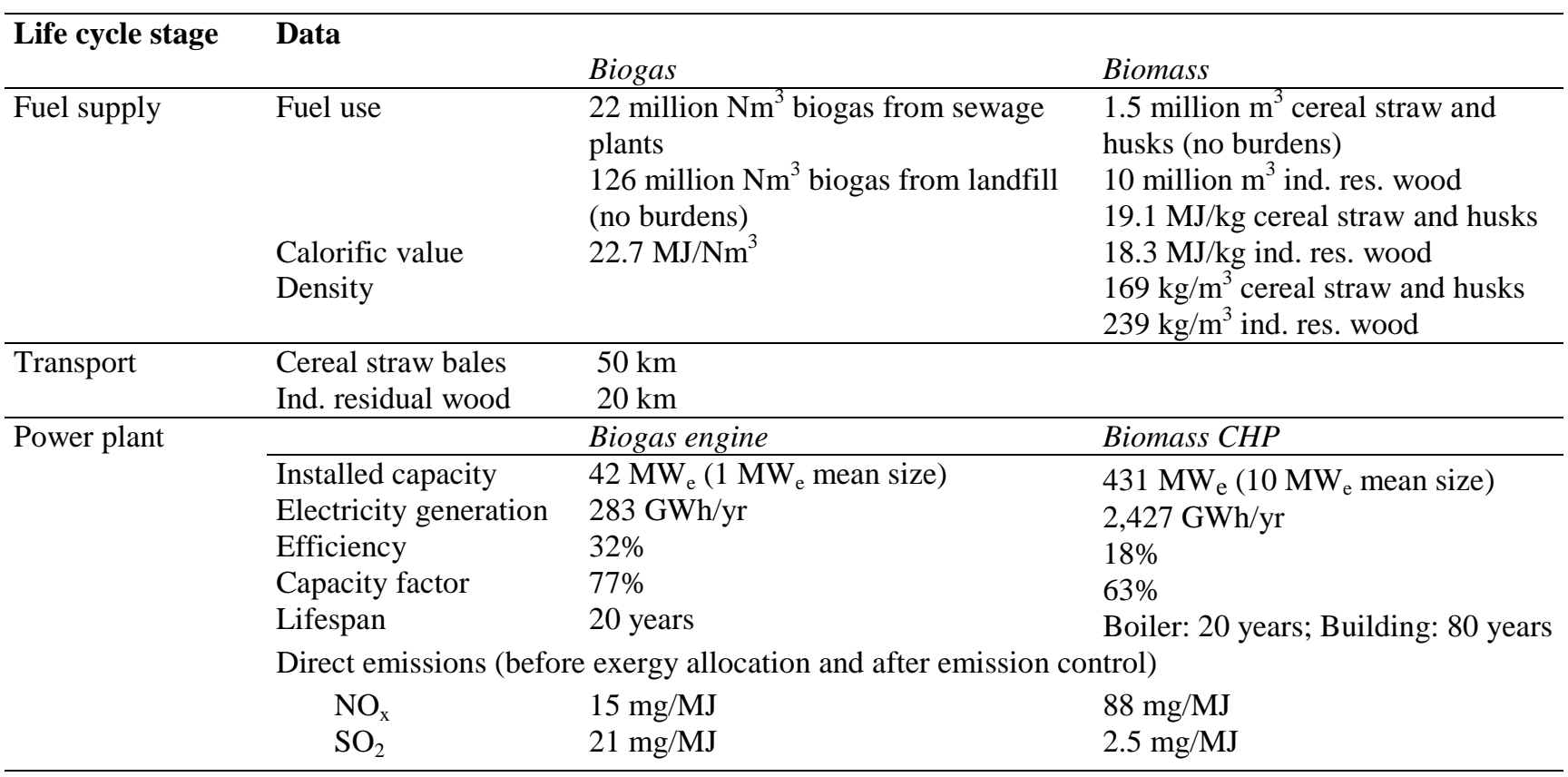

\subsubsection{Electricity from biomass}

Chile has 19 biomass plants, which provide around 3.5\% of the total electricity generation (Table 1). The majority of this (79\%) is produced by the pulp and paper industry and the rest by energy companies. The pulp and paper industry generates electricity from industrial wood residues (73\%) and black liquor (27\%). The energy companies also use industrial wood residues $(60 \%)$ as well as agricultural crop residues (40\%) [32]. Electricity is co-generated with heat in a CHP plant. The former is supplied to the central interconnected system (SIC) and the heat is used for the wood drying process in the pulp and paper industry and wood-using energy companies. There is only one plant that uses agricultural crop residues (cereal straw and husks) and releases the heat without using it.

For the modelling of biomass electricity, it has been assumed that all the feedstock comes from industrial wood residues and agricultural crop residues (Table 6 and Table S1 in the SI). The black liquor has been omitted due to its low contribution to the total electricity generation $(<1 \%)$ and a lack of data. No environmental burdens have been considered for agricultural residues as they have no economic value and are normally burned at the farm. However, industrial wood residues have an economic value. Hence, their impacts have been estimated using economic allocation, based on their contribution of $15 \%$ to the total revenue from wood products [33, 34]. Exergy allocation has been used to allocate the impacts between the electricity (77\%) and heat [30]. 
A distance of $50 \mathrm{~km}$ has been assumed for the cereal straw and husks and $20 \mathrm{~km}$ for the wood residues. Emissions from the CHP plants have been estimated using GEMIS [31]. The main input parameters used to estimate the emissions were the mean size of the CHP plants $\left(10 \mathrm{MW}_{\mathrm{e}}\right)$, efficiency (18\%) and standard bag filters for control of particulates. The CHP plant from the Ecoinvent database has a $580 \mathrm{~kW}_{\mathrm{e}}$ capacity, but the average power capacity of CHP plants in Chile is $10 \mathrm{MW}_{\mathrm{e}}$. Therefore, the impacts have been scaled down accordingly (see section 2.2.3).

\subsubsection{Electricity from wind and solar PV}

Currently, 16 onshore wind farms are in operation with a total capacity of $831 \mathrm{MW}_{\mathrm{e}}$ (Table S3). There are no offshore wind installations in Chile. Most of the wind farms have $2 \mathrm{MW}_{\mathrm{e}}$ turbines (Table 7). Inventory data for this size of turbine have been obtained from Kouloumpis et al. [35], based on a Vestas design. This type has been selected because 59\% of the 407 wind turbines in Chile are Vestas. A capacity factor of $27 \%$ has been considered.

The 19 solar PV plants in Chile have a total installed capacity of $401 \mathrm{MW}_{\mathrm{e}}$ and an average capacity factor of $24 \%$ (Table 7). The majority of solar electricity in the country is provided by groundmounted mono- and multi-crystalline PV (83\%), with the balance supplied by thin-film technologies [36-38]. For modelling purposes, it has been assumed that all the solar electricity is generated by multi-crystalline PV due to a lack of data for thin-film and mono-crystalline panels. The average lifespan of solar panels has been assumed at 30 years and the annual degradation rate $0.7 \%$ [39-41].

\subsubsection{Hydroelectricity}

Ten reservoirs and 95 run-of-river power plants are in use in Chile (Table S2 in the SI), with a total capacity of 3,726 $\mathrm{MW}_{\mathrm{e}}$ and 2,722 $\mathrm{MW}_{\mathrm{e}}$ respectively (Table 7). All the hydropower plants are located between the Valparaiso and Los Lagos regions, in the Andes mountains range, an area with a dry temperate climate [5]. The hydroelectricity system has been modelled considering construction, operation and decommissioning of the plants. Emissions of methane have been considered for the reservoir technology, arising from organic matter in the water body and anaerobic activity over the lifespan of the reservoir [42]. Many factors influence the production of methane in reservoirs, such as water depth, climate, flooded vegetation, organic load of tributaries and reservoir dimensions. As specific data were not available for these emissions, the Ecoinvent data for the Alpine-region reservoirs have been used instead, considering that this region has similar geographic and climate conditions to Chile. Methane emissions of $14 \mathrm{mg} \mathrm{CH} / \mathrm{kWh}$ have thus been assumed. No emissions have been considered for run-of-river due to the low residence time of the water. For the reservoir plants, the impacts from construction correspond to the Ecoinvent data for a plant of $95 \mathrm{MW}_{\mathrm{e}}$, and for the run-of-river, for an $8.6 \mathrm{MW}_{\mathrm{e}}$ plant [43]. In Chile, the average size of the former is $373 \mathrm{MW}_{\mathrm{e}}$ and the latter $29 \mathrm{MW}_{\mathrm{e}}$; therefore, the data in Ecoinvent have been scaled up (section 2.2.3).

Table 7. Summary of inventory data and assumptions for hydropower [21, 26], wind and solar PV [2, 26].

\begin{tabular}{lllll}
\hline Parameter & Solar PV & Onshore wind & Reservoir & Run-of-river \\
\hline Installed capacity & $401 \mathrm{MW}_{\mathrm{e}}$ & $831 \mathrm{MW}_{\mathrm{e}}$ & $3,726 \mathrm{MW}_{\mathrm{e}}$ & $2,722 \mathrm{MW}_{\mathrm{e}}$ \\
& $($ multi-crystalline) & $\left(2 \mathrm{MW}_{\mathrm{e}}\right.$ mean) & $\left(373 \mathrm{MW}_{\mathrm{e}}\right.$ mean $)$ & $\left(29 \mathrm{MW}_{\mathrm{e}}\right.$ mean $)$ \\
Electricity generation & $464 \mathrm{GWh} / \mathrm{yr}$ & $1,425 \mathrm{GWh} / \mathrm{yr}$ & $13,092 \mathrm{GWh} / \mathrm{yr}$ & $10,450 \mathrm{GWh} / \mathrm{yr}$ \\
$\begin{array}{l}\text { Capacity factor } \\
\text { Lifespan }\end{array}$ & $24 \%$ & $27 \%$ & $43 \%$ & $60 \%$ \\
& 30 years & Moving parts: 20 years & 100 years & 80 years \\
$\begin{array}{l}\text { Degradation rate } \\
\text { Methane missions }\end{array}$ & $0.7 \% / \mathrm{yr}$ & Fixed parts: 40 years & \\
\hline
\end{tabular}




\subsubsection{Infrastructure}

As mentioned earlier, some of the power plants in Ecoinvent had either larger or smaller capacities than those installed in Chile. Therefore, it has been necessary to scale their impacts accordingly. This has been done for hydropower, biogas, and biomass power plants and for the regasification plant for natural gas. In LCA, the environmental impacts are normally scaled linearly with respect to the size of infrastructure. However, due to the economies of scale, this relationship is likely to be non-linear. Therefore, the "economies of scale" method, typically used for scaling the capital costs of process plants, has been applied. This is based on the approach in Sinnott [44], adapted for use in LCA [45]:

$\mathrm{I}_{\mathrm{A}}=\mathrm{I}_{\mathrm{R}} *\left(\frac{\mathrm{S}_{\mathrm{A}}}{\mathrm{S}_{\mathrm{R}}}\right)^{0.6}$

where:

$I_{A} \quad$ environmental impacts of the actual infrastructure

$I_{R} \quad$ environmental impacts of reference infrastructure

$S_{A} \quad$ size or dimensions of the actual infrastructure

$S_{R} \quad$ size or dimensions of reference infrastructure

0.6 the economy of scale factor.

\subsubsection{End-of-life waste management}

Copper, aluminium and reinforcing and stainless steel have been assumed to be recycled after the decommissioning of power plants. The system has been credited for this using the "avoided burdens (net scrap)" approach [46-50]. This takes into account the recycled content of metals in the construction and their recycling rates at the end of life. If the recycled content is lower than the recycling rate, a credit is given to the system; otherwise, no credits are included. The recycled content for different metals has been assumed as follows: aluminium $32 \%$, copper $18 \%$ and steel $37 \%$ [51]. Data for recycling of structural metals in Chile have not been available so a recycling rate of $50 \%$ has been assumed, with the rest landfilled.

Only $1 \%$ of the ash from coal plants is recycled in cement factories due to the large deposits of pozzolans and lime; hence, its recycling is not considered in the study.

\subsubsection{Temporal evolution of impacts}

The temporal evolution of the impacts from electricity generation in Chile focuses on the years 2004, 2009 and 2014. These years have been chosen as they are representative of changes in the electricity mix over the period. The impacts have been estimated using the data in Figure 1 and Table 8 . As can be seen, the share of hydropower has declined by $10 \%$ over the period, from $43 \%$ in 2004 to $33.7 \%$ in 2014 . Natural gas followed a more drastic trend, reducing its contribution from $36 \%$ in 2004 to $9 \%$ in 2009 , before going up to $14 \%$ in 2014 . The share of coal, on the other hand, has been increasing and it is now the main contributor in the mix, having surpassed hydropower. Oil has a low contribution now, but between 2007 and 2010 it peaked at $18 \%$, caused by the steady increase in electricity demand and the shutdown of gas power plants due to a disruption in gas supply.

Each year has been modelled taking into account the values of different parameters, such as the electricity and fuel mixes, capacity factors, heating values, etc. The detailed life cycle inventory for each year can be found in Tables S4-S6 in the SI. 
Table 8. Electricity generation and contribution of different sources for the period 2004-2014 [2, 52].

\begin{tabular}{lrrr}
\hline & $\mathbf{2 0 0 4}$ & $\mathbf{2 0 0 9}$ & $\mathbf{2 0 1 4}$ \\
\hline Electricity generation (TWh) & 48.6 & 56.6 & 69.8 \\
Contribution (\%) & & & \\
$\quad$ Coal & 19.4 & 27.8 & 41.4 \\
Oil & - & 18.3 & 3.9 \\
Natural gas & 36.1 & 8.7 & 14.3 \\
Biogas & - & - & 0.4 \\
Biomass & 1.3 & 1.7 & 3.5 \\
Solar PV & - & - & 0.7 \\
Wind & - & - & 2.0 \\
Hydropower & 43.1 & 43.5 & 33.7 \\
\hline
\end{tabular}

2.3. Environmental impact assessment

GaBi v7.0 software [22] has been used to model the system. The latest version of CML 2001 (April 2016) impact assessment method [46] has been applied to determine the environmental impacts. This methodology considers the following 11 environmental impacts all of which have been estimated: global warming potential (GWP), human toxicity potential (HTP), abiotic depletion potential of elements (ADP), abiotic depletion potential of fossil resources $\left(\mathrm{ADP}_{\text {fossil }}\right)$, acidification potential (AP), eutrophication potential (EP), ozone layer depletion potential (ODP), photochemical oxidants creation potential (POCP), freshwater aquatic ecotoxicity potential (FAETP), marine aquatic ecotoxicity potential (MAETP) and terrestrial ecotoxicity potential (TETP).

\section{Results and discussion}

3.1. Environmental impacts of technologies

Life cycle environmental impacts of the technologies are summarised and compared using a heat map in Table 9. As can be seen, coal is environmentally the least sustainable option for eight of the impacts while hydropower is the best option for all the categories, followed by biogas and wind. The most impacting life cycle stages are fuel production and power plant operation, each contributing on average $40 \%$ to the total impacts of fossil, biogas and biomass options (Figure 3 ). For the rest of the renewable technologies, power plant construction represents the most significant stage with an average contribution of around $90 \%$. Each impact category is analysed in detail in the following sections.

Table 9. Environmental impacts of electricity technologies in Chile in the base year (2014).

\begin{tabular}{|c|c|c|c|c|c|c|c|c|c|c|c|c|}
\hline \multirow[b]{2}{*}{ Impacts per $\mathrm{kWh}$} & \multicolumn{12}{|c|}{ Electricity sources and technologies } \\
\hline & $\begin{array}{l}\text { Coal } \\
\text { PC }^{\mathrm{a}}\end{array}$ & $\begin{array}{l}\text { Oil } \\
\text { CC }^{\text {a }}\end{array}$ & $\begin{array}{l}\text { Oil } \\
\text { OC }^{\text {a }}\end{array}$ & $\begin{array}{l}\text { Oil } \\
\text { DE }^{\mathrm{a}}\end{array}$ & $\begin{array}{l}\text { Gas } \\
\text { CC }^{\text {a }}\end{array}$ & $\begin{array}{l}\text { Gas } \\
\text { OC }^{\text {a }}\end{array}$ & Biogas & $\begin{array}{c}\text { Biomass } \\
\text { CHP }^{\mathrm{a}}\end{array}$ & $\begin{array}{l}\text { Solar } \\
\mathrm{PV}^{\mathrm{a}}\end{array}$ & $\begin{array}{c}\text { Wind } \\
\text { onshore }\end{array}$ & $\begin{array}{l}\text { Hydro } \\
\text { reservoir }\end{array}$ & $\begin{array}{l}\text { Hydro } \\
\text { RoR }^{\mathrm{a}}\end{array}$ \\
\hline GWP [g CO $\mathrm{CO}_{2}$ eq.] & 1,039 & 836 & 988 & 924 & 632 & 975 & 36 & 50 & 40 & 8 & 3 & 2 \\
\hline HTP [g DCB eq.] & 394 & 100 & 126 & 97 & 46 & 74 & 9 & 120 & 53 & 25 & 3 & 2 \\
\hline ADP $[\mu \mathrm{g} \mathrm{Sb}$ eq.] & 33 & 121 & 154 & 191 & 27 & 47 & 36 & 30 & 1,165 & 81 & 6.1 & 5.4 \\
\hline $\mathrm{ADP}_{\text {fossil }}[\mathrm{kJ}]$ & 10,342 & 9,454 & 12,213 & 11,807 & 8,713 & 14,454 & 312 & 595 & 419 & 91 & 20 & 17 \\
\hline $\mathrm{AP}\left[\mathrm{mg} \mathrm{SO} \mathrm{S}_{2}\right.$ eq. $]$ & 6,070 & 4,131 & 8,783 & 7,911 & 682 & 473 & 340 & 776 & 254 & 33 & 8 & 6 \\
\hline $\mathrm{EP}\left[\mathrm{mg} \mathrm{PO}_{4}^{-3}\right.$ eq. $]$ & 1,913 & 666 & 818 & 1,546 & 193 & 149 & 40 & 218 & 104 & 21 & 3 & 3 \\
\hline ODP [ $\mu$ g R11 eq.] & 15 & 101 & 129 & 125 & 0.9 & 1.4 & 2.9 & 5.4 & 6.3 & 0.5 & 0.2 & 0.1 \\
\hline POCP [mg $\mathrm{C}_{2} \mathrm{H}_{4}$ eq. $]$ & 298 & 253 & 462 & 779 & 75 & 87 & 34 & 424 & 22 & 3.6 & 0.9 & 0.7 \\
\hline FAETP [g DCB eq.] & 308 & 28 & 40 & 58 & 11 & 21 & 7.4 & 8.3 & 49 & 26 & 0.8 & 0.7 \\
\hline MAETP [kg DCB eq.] & 2,403 & 53 & 69 & 76 & 15 & 26 & 10 & 12 & 173 & 18 & 1.4 & 1.2 \\
\hline TETP [mg DCB eq.] & 2,200 & 770 & 830 & 1,150 & 300 & 420 & 210 & 580 & 450 & 570 & 90 & 70 \\
\hline
\end{tabular}




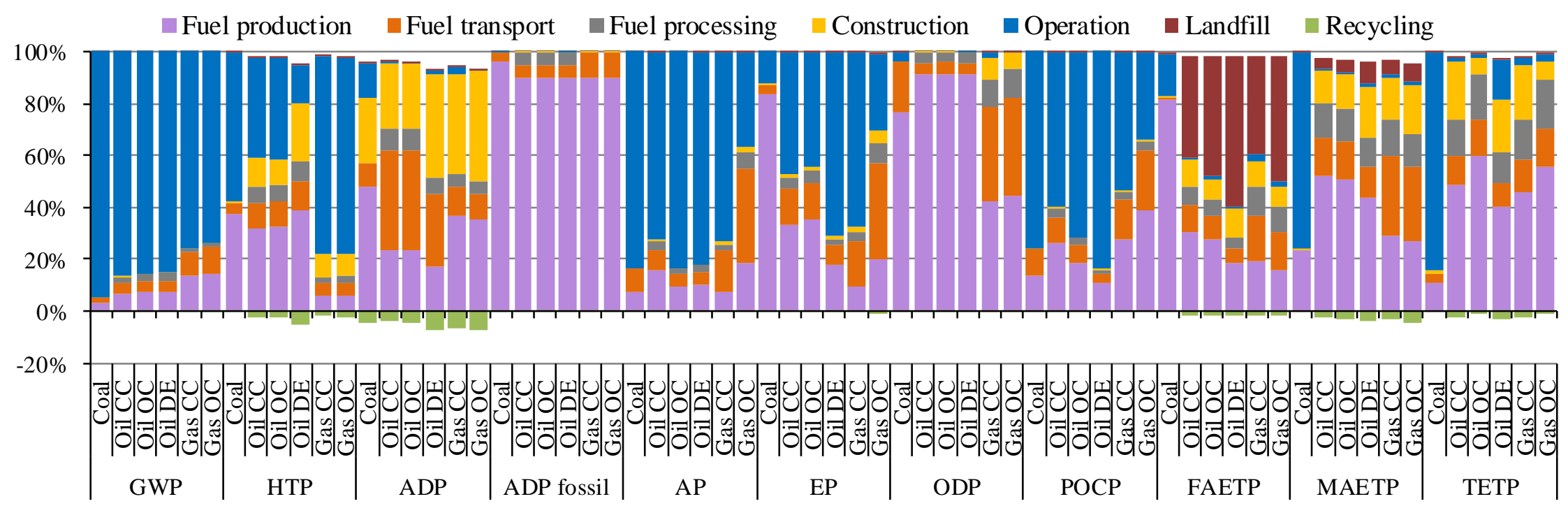

(a)

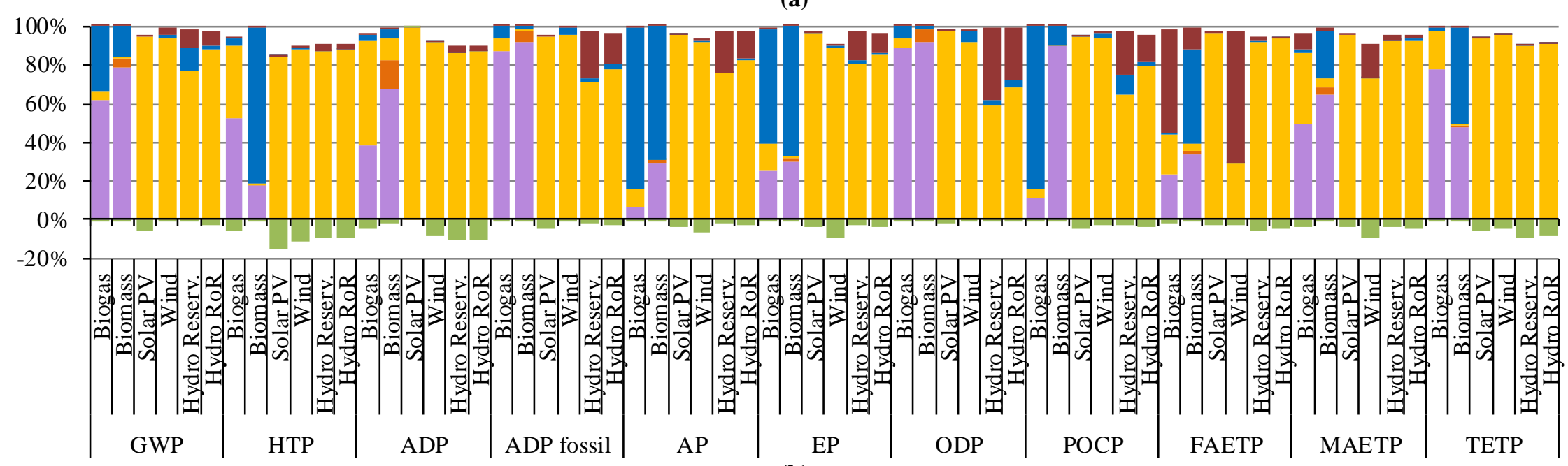

(b)

Figure 3. Contribution of life cycle stages to environmental impacts by power technology. (a) Fossil fuel technologies. (b) Renewable technologies [Hydro RoR: Hydropower from run-of-river, Hydro Reserv.: Hydropower from reservoirs] 


\subsubsection{Global warming potential (GWP)}

Run-of-river and reservoir hydropower plants, along with wind electricity, have the lowest GWP ( $<8 \mathrm{~g} \mathrm{CO}_{2}$ eq./kWh). By contrast, the impact of coal power is around 130 times higher $(1,039 \mathrm{~g})$. Oil power has a GWP similar to coal (836-988 $\mathrm{g} \mathrm{CO}_{2}$ eq. $\left./ \mathrm{kWh}\right)$ because open cycle power plants have low efficiency (31\% on average). Among the fossil-based options, natural gas in combined cycle plants generates electricity with the lowest GWP $\left(632 \mathrm{~g} \mathrm{CO}_{2}\right.$ eq./kWh $)$ due to a higher efficiency (47\%). Even so, it still has 13 times higher emissions than biomass (50 $\mathrm{g} \mathrm{CO}_{2}$ eq./ $/ \mathrm{kWh}$ ), the worst renewable option for this impact. The latter, along with solar $\mathrm{PV}$, has a four times higher impact than hydropower and wind.

For fossil-fuel power plants, their operation contributes more than $76 \%$ to the GWP due to the emissions associated with the burning of fuels. In the case of renewable options, two groups can be distinguished. The first group comprises biomass and biogas, where the impact is mainly due to fuel production (62\% for biogas and $79 \%$ for biomass) and power plant operation (33\% for biogas and $15 \%$ for biomass). $\mathrm{CO}_{2}$ is the main GHG as a result of fossil fuel used in machinery and because of fugitive emissions of $\mathrm{CH}_{4}$ during the anaerobic digestion and storage of sewage sludge for biogas production $[53,54]$. In the operation stage, $\mathrm{N}_{2} \mathrm{O}$ is the main GHG emitted during the combustion in power plants for both biogas and biomass power options.

The second group consists of hydropower, wind and solar PV where the contribution to GWP is mainly associated with the construction stage, with $\mathrm{CO}_{2}$ being the main GHG. Cement and steel production, along with diesel used in the construction machinery, are the main contributing processes for hydropower plants. The same processes, plus the use of glass fibre in wind turbines, contribute to GWP of wind electricity. Additionally, the production of crystals and wafers is the main contributor to the impact in the manufacture of solar PV panels. Recycling reduces the GWP across the technologies to a small degree. Only solar PV shows a slightly higher reduction in GWP $(5 \%)$ due to the system credits for the avoidance of virgin aluminium production.

\subsubsection{Human toxicity potential (HTP)}

Coal power has the highest HTP among all the technologies evaluated (394 g DCB eq./kWh), followed by open cycle oil plants and biomass (126 and $120 \mathrm{~g}$, respectively). Among the fossil fuel technologies, natural gas in combined cycle plants is the best option for this impact (46 g DCB eq./kWh). It is even better than renewable technologies, such as solar PV and biomass (53 and $120 \mathrm{~g} \mathrm{DCB}$ eq./kWh, respectively). Both types of hydropower technologies have the lowest HTP ( $<3 \mathrm{~g}$ DCB eq./kWh). The next best source of electricity is wind $(25 \mathrm{~g}$ DCB eq./kWh).

Power plant operation and fuel production are the two main contributing stages for fossil fuel technologies with contributions of 14\%-76\% and 6\%-79\%, respectively. Coal emits hydrogen fluoride into the atmosphere during combustion and vanadium is emitted to water bodies due to the disposal of ashes. Both the combustion and ash disposal cause 34\% of HTP associated with coal electricity. The release of selenium related to the overburden in mines in fuel production contributes $19 \%$ to the total. Other combustion options, such as biomass and open and combined cycle oil power plants, generate significant air emissions of polycyclic aromatic hydrocarbon $(\mathrm{PAH})$ as a result of incomplete combustion which is in turn due to lower flame temperatures and an inadequate $\mathrm{C} / \mathrm{O}$ ratio [55]. Biomass has the highest emissions of $\mathrm{PAH}$, followed by open cycle oil power plants, with contributions to HTP equivalent to 67 and $35 \mathrm{~g}$ DCB eq./kWh, respectively. In the case of solar PV, wind and hydropower, the construction stage is the principal contributor, mainly due to the release of 
chromium (+VI) in the stainless steel production process. Additionally, PV panel production emits selenium, vanadium and thallium.

End-of-life recycling reduces HTP significantly, mostly for the renewable options with the exception of biomass. Solar PV has the highest reduction (18\%) while for the rest of renewable technologies the reduction ranges between 6\%-11\%. Oil power from diesel engines is the only fossil fuel option that has a reduction in HTP greater than 5\%. Diesel engine, biogas and wind options benefit from the credits for copper recycling. The credits for hydropower options are related to alloyed steel recycling. For solar PV, the main credits come from the recycling of aluminium used for frames, mounting structures and inverters.

\subsubsection{Abiotic depletion potential of elements (ADP)}

Solar PV has the highest depletion of elements $(1,165 \mu \mathrm{g} \mathrm{Sb}$ eq./kWh). This is six times greater than the second largest impact - power from oil in diesel engines $(191 \mu \mathrm{g})-$ and about 190 times larger than the least impactful technology, hydropower $(5-6 \mu \mathrm{g})$. The three oil power technologies have the largest ADP (121-191 $\mu \mathrm{g} \mathrm{Sb}$ eq./kWh) among the fossil fuel alternatives, with values four times higher than coal $(33 \mu \mathrm{g})$ and natural gas power (27-47 $\mu \mathrm{g})$. Wind also has an ADP higher than coal and natural gas $(81 \mu \mathrm{g} \mathrm{Sb}$ eq./kWh, $)$. Natural gas, biogas and biomass have the lowest ADP, ranging from 27 to $36 \mu \mathrm{g}$ Sb eq./kWh.

Fuel production and construction are the main contributing stages for fossil fuel options (48\%-77\%), biogas (93\%) and biomass (78\%). Construction is the main hotspot for solar PV, wind and hydropower, with a contribution of $85 \%$. The influence of the construction stage is correlated with the capacity factors and lifespan: its influence is lower for technologies with high capacity factors and long lifespans, like hydropower, coal, biogas and natural gas. Copper is the main element depleted by the construction of coal, gas, oil, biogas and wind installations. For solar PV, gold and silver, used for electronic parts, are the main hotspots. As aluminium is an abundant element, its recycling has negligible positive effect on the ADP of solar PV. On the other hand, recycling of metals from coal, natural gas, wind and hydropower plants reduces their impact by $5-10 \%$.

\subsubsection{Abiotic depletion potential of fossil fuels $\left(A D P_{\text {fossil }}\right)$}

Fossil-based technologies have $\mathrm{ADP}_{\text {fossil }}$ values ranging from $8,713 \mathrm{~kJ} / \mathrm{kWh}$ (gas combined cycle) to $14,454 \mathrm{~kJ} / \mathrm{kWh}$ (gas open cycle). For the renewable options, the impact varies from $17 \mathrm{~kJ} / \mathrm{kWh}$ (run-of-river hydropower) to $595 \mathrm{~kJ} / \mathrm{kWh}$ (biomass). Biomass, biogas and solar $\mathrm{PV}$ have the highest $\mathrm{ADP}_{\text {fossil }}$ among the renewables $(312-595 \mathrm{~kJ} / \mathrm{kWh})$ but this is still only $5 \%$ of the average impact of the fossil fuel options $(11,164 \mathrm{~kJ} / \mathrm{kWh})$.

The extraction of fuel is the main contributor (90\%) for the fossil fuel options. For the renewables, $\mathrm{ADP}_{\text {fossil }}$ is mainly caused by the consumption of fossil fuel for the production of construction materials, such as cement and metals, and for the use of machinery associated with soil movement in the case of hydropower plants and with logging for biomass. Hence, this impact is mainly associated with the construction stage $(85 \%)$ for wind, solar and hydropower options, while for biogas and biomass, extraction of fuel is the most significant process $(90 \%)$.

\subsubsection{Acidification potential (AP)}

Open cycle oil and coal power are the options with the highest AP: 8,783 and 6,070 mg $\mathrm{SO}_{2}$ eq./kWh, respectively. This is due to $\mathrm{SO}_{2}$ emissions from fuel combustion. Among the renewables, biomass is the worst option for this impact (776 $\mathrm{mg} \mathrm{SO}_{2}$ eq. $/ \mathrm{kWh}$ ) because of $\mathrm{NO}_{\mathrm{x}}$ emissions generated in low-temperature flames. Electricity from biomass has higher 
impact than natural gas (473-682 $\mathrm{mg} \mathrm{SO}_{2}$ eq./kWh). Solar PV also has a high AP compared to the remaining renewables ( $254 \mathrm{mg} \mathrm{SO}$ eq. $/ \mathrm{kWh}$ ). Still, it is about half the lowest impact from natural gas but about eight times greater than the values for hydropower $\left(6-8 \mathrm{mg} \mathrm{SO}_{2}\right.$ eq./kWh) and wind (33 mg), the best options for this category.

Plant operation is the most significant life cycle stage, with an average contribution of $72 \%$ for fossil fuel options, $84 \%$ for biogas and $69 \%$ for biomass. As mentioned earlier, this is due to the emissions of $\mathrm{SO}_{2}$ and NOx. These are also generated during the production and construction of solar PV, wind and hydropower plants. The main processes causing the AP of solar PV are the use of solar-grade silicon for manufacture of wafers, aluminium alloy and copper for construction and mounting of panels, solar glass for solar cells and electricity for manufacturing of panels. For wind and hydropower options, the production of copper and steel, together with the fabrication of glass fibres for wind turbines, are the most contributing processes. An average of $86 \%$ of this impact is attributed to the construction of these plants.

\subsubsection{Eutrophication potential (EP)}

Coal power has the highest EP $\left(1,913 \mathrm{mg} \mathrm{PO}_{4}{ }^{3-} \mathrm{eq} . / \mathrm{kWh}\right)$, followed by the oil technologies. Regarding the latter, the EP of diesel engines $\left(1,546 \mathrm{mg} \mathrm{PO}_{4}{ }^{3-}\right.$ eq./kWh $)$ is nearly double the impact from the combined and open cycle plants (666 and $818 \mathrm{mg} \mathrm{PO}_{4}{ }^{3-}$ eq./kWh, respectively). Electricity from biomass has the highest EP (218 $\mathrm{mg} \mathrm{PO}_{4}{ }^{3-}$ eq. $\left./ \mathrm{kWh}\right)$ among the renewables and even greater than the natural gas options $(149-193 \mathrm{mg})$. Solar PV is the second worst renewable alternative with $104 \mathrm{mg} \mathrm{PO}_{4}{ }^{3-}$ eq./kWh. Hydropower and wind are again the best options ( 3 and $21 \mathrm{mg} \mathrm{PO}_{4}{ }^{3-}$ eq./kWh, respectively).

Coal extraction (84\%) and power plant operation (12\%) are the main hotspots for coal power. Phosphate, released during the extraction of coal, is the main burden followed by $\mathrm{NO}_{\mathrm{x}}$ emitted during coal combustion. The plant operation causes around $50 \%$ of the EP for the oil, biomass and natural gas options, also related to $\mathrm{NO}_{\mathrm{x}}$ emissions from fuel combustion. Construction is the main contributing stage for hydropower, wind and solar PV. The copper content in PV panels and inventers, together with electricity consumption for panels manufacture, cause most of the EP of this technology. This is specifically due to phosphate emissions from copper refineries and coal in the electricity mix of countries where solar PV is produced, such as China.

\subsubsection{Ozone depletion potential (ODP)}

The oil technologies have the highest ODP (101-129 $\mu \mathrm{g}$ R11 eq./kWh). The next worst option is coal power, but its impact is seven times lower $(15 \mu \mathrm{g} \mathrm{R} 11$ eq./kWh). Solar PV has the highest ODP among the renewables, followed by biomass power $(6.3$ and $5.4 \mu \mathrm{g}$ R11 eq./kWh, respectively). The natural gas options have lower impact (0.9-1.4 $\mu \mathrm{g} \mathrm{R} 11 \mathrm{eq} . / \mathrm{kWh})$ than biogas, biomass and solar PV $(2.9-6.3 \mu \mathrm{g})$. The reason for this is that natural gas is shipped in liquefied form, avoiding long-distance pipelines that use ozone-depleting fire suppressants. The hydropower options have the lowest impact (0.1-0.2 $\mu \mathrm{g}$ R11 eq./kWh), followed by wind $(0.5 \mu \mathrm{g})$.

The main contributing stage for the fossil-based technologies is fuel production (73\%). The extraction and processing of crude oil produces significant amounts of ozone-depleting substances [56]. As mentioned in section 2.2.1, there are two coal power plants that also use petcoke as a secondary fuel. This increases the ODP of coal power due to the petcoke-related burdens from the combustion of heavy fuel oil in the refinery's furnace. Solar PV panel production releases chlorodifluoromethane (HCFC-22) emissions that contribute to ODP. These gases are intermediate compounds for the production of fluorocarbon film used for 
solar-glass coating [57]. Hence, construction is the main contributing stage for solar PV (98\%). Halon 1301 is emitted in the life cycle of biomass power, mainly associated with combustion of diesel in machinery during logging and wood transport to sawmills. As a result, the fuel production stage causes $89 \%$ of the impact.

It should be noted, however, that the estimates of ODP have a margin of uncertainty due to the Montreal Protocol which has led to a reduction in use of ozone-depleting substances in many regions and sectors [58].

\subsubsection{Photochemical oxidants creation potential (POCP)}

Power from diesel engines is the worst option for POCP (779 $\mathrm{mg} \mathrm{C}_{2} \mathrm{H}_{4}$ eq. $/ \mathrm{kWh}$ ), followed by open cycle oil plants (462 mg) and biomass (424 mg). The last has a $40 \%$ higher impact than coal (297 $\mathrm{mg} \mathrm{C}_{2} \mathrm{H}_{4}$ eq./kWh) and around five times greater than gas $(75-87 \mathrm{mg})$. Solar $\mathrm{PV}$ and biogas are the least preferred renewable options for this category (22 and $34 \mathrm{mg} \mathrm{C}_{2} \mathrm{H}_{4}$ eq./kWh, respectively). Hydropower and wind have the lowest POCP (07-0.9 and $3.6 \mathrm{mg}$ $\mathrm{C}_{2} \mathrm{H}_{4}$ eq./kWh).

Power plant operation is the main contributor to the impact from coal (76\%), oil $(60 \%-84 \%)$ and biogas $(84 \%)$ power due to the emissions of $\mathrm{SO}_{2}, \mathrm{NO}_{\mathrm{x}}, \mathrm{CO}$ and non-methane volatile organic compounds (NMVOC). Fuel production is the key hotspot (90\%) for biomass electricity, related to NMVOC emissions from the logging machinery and transport to sawmills. For solar PV, wind and hydropower, the construction stage causes $83 \%$ of POCP. Like the AP, the POCP of solar PV is largely due to the use of materials (solar grade silicon, aluminium alloy and copper) and electricity for the manufacturing of panels.

\subsubsection{Freshwater, marine and terrestrial ecotoxicity potentials (FAETP, MAETP and TETP)} Coal has the highest ecotoxicity potentials, at least double the impacts of the next closest option, oil power from diesel engines. Solar PV is the worst renewable technology for FAETP and MAETP, while biomass has the largest TETP. Open cycle natural gas, together with wind power, have FAETP and MAETP twice as high as the combined cycle natural gas, biogas and biomass (see Table 9). Hydropower is the best performing option across the three impacts.

For coal, plant operation is the main contributor to MAETP (76\%) and TETP (84\%), and fuel production to FAETP (82\%). For the other fossil fuel options, fuel production, fuel transport and plant construction are significant contributing stages for the three impacts. Additionally, fuel processing is important for TETP and landfill disposal for FAETP.

The main burdens causing FAETP of coal power are nickel, beryllium, cobalt and vanadium emitted to water during coal extraction. For oil power from diesel engines, leaching of copper from landfills to water bodies is the main contributor to FAETP. In the case of solar PV, the vast majority of FAETP (97\%) is related to the release of beryllium, cobalt, copper and vanadium to water during the production of photovoltaic cells and inverters.

For MAETP, plant operation is the most significant contributor for coal power mainly due to the hydrogen fluoride emission during combustion. The impact from diesel engines and solar PV is associated with hydrogen fluoride and beryllium emissions from crude oil refining and the production of components for solar PV systems.

Mercury emissions from combustion are the main burden for TETP of coal and oil power. For the latter as well as for solar PV, TETP is caused by chromium, vanadium and mercury generated in the production of steel. 


\subsubsection{Comparison of results with literature}

As shown in Figure 4, most of the impacts of fossil fuel options estimated in this work are within the ranges found in the literature, with some exceptions. This includes ADP for coal (33 $\mu \mathrm{g} \mathrm{Sb}$ eq. $/ \mathrm{kWh}$ ) which is slightly below the lowest literature value (36 $\mu \mathrm{g} \mathrm{Sb}$ eq.); see Figure 4a. This impact is associated mostly with the infrastructure and in Chile, coal power plants have high capacity factors $(81 \%)$ and good efficiency $(38 \%-41 \%)$ as most of the installations are new and the coal has a high heating value $(25.8 \mathrm{MJ} / \mathrm{kg})$. All these factors imply a lower requirement of resources for coal production and transport per $\mathrm{kWh}$. Furthermore, the ODP for coal ( $15 \mu \mathrm{g} \mathrm{R} 11$ eq.) is above the maximum value in the range (11 $\mu \mathrm{g}$ R11 eq.). The use of petcoke as a secondary fuel in coal power plants explains this difference.

For the three oil technologies, TETP is below the range, while MAETP and HTP are within the lower range of the literature values (Figure $4 \mathrm{~b}$ ). These impacts are mainly associated with the release of heavy metals and toxic compounds, mostly in oil production (ecotoxicities), and from combustion in power plants (HTP). Heavy fuel oil is the main fuel considered in the literature for oil power [56]. In Chile, oil power plants are fed by diesel instead of heavy fuel oil. Because oil (diesel) used in Chile has a higher calorific value $(45.6 \mathrm{MJ} / \mathrm{kg})$ than heavy fuel oil $(41.1 \mathrm{MJ} / \mathrm{kg})$, the consumption of fuel is lower, leading to lower ecotoxicities. The lower HTP is justified because the combustion of heavy fuel oil produces higher emissions of $\mathrm{PAH}$, nickel and vanadium than the combustion of diesel [56].

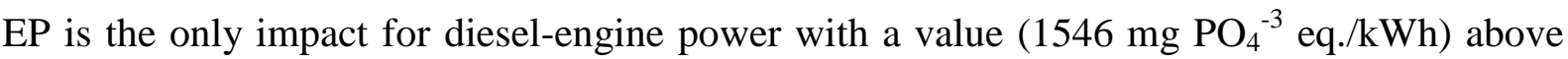
the literature range $(1460 \mathrm{mg})$. According to the literature, the average efficiency of oil technologies is 38\% [56], somewhat higher than the average efficiency in Chile (36\%). As indicated in section 3.1.6, operation is a significant stage for oil electricity; therefore, a lower efficiency leads to a higher impact than in the literature. It can be noted that even though open cycle plants have a lower efficiency (34\%) than diesel engines, their EP is within the literature range. This is due to $\mathrm{NO}_{\mathrm{x}}$ emissions $(265 \mathrm{mg} / \mathrm{MJ})$ being $68 \%$ lower than from diesel engines (829 $\mathrm{mg} \mathrm{NO} / \mathrm{MJ})$.

As can be seen in Figure 4c, both natural gas technologies have ODP (0.9-1.4 $\mu$ g R11 eq.) significantly below the minimum value reported in the literature $(12.7 \mu \mathrm{g}$ R11 eq.). This is because the natural gas is liquefied and shipped, avoiding the use of long-distance pipelines that are associated with significant emissions of ozone-depleting substances, as mentioned in section 3.1.7.

The impacts of renewable technologies in the current study fall within the lower range of the literature values, and for some categories, below the range. For example, biogas power has lower values for GWP, HTP, ADP, AP and POCP; for the rest of the impacts, the values are in the lower part of the range (Figure 4d). According to the countries analysed in the literature, the biogas mix is made up of $52 \%$ biogas from anaerobic digestion of biowaste and $48 \%$ sewage sludge. However, in Chile, $85 \%$ of biogas comes from landfills and the rest from digestion of sewage sludge. As landfill gas is assumed to be burden free, the impacts of biogas electricity in the current study are $44 \%-88 \%$ lower than those reported in the literature.

The ADP and ecotoxicity impacts from biomass power are below the literature values, while POCP and ODP are above the range. In the literature [54, 59], biomass power is mainly generated using softwood (72\%), such as cereal straw, husks and sawdust. Furthermore, the capacity factor is $23 \%$ and ashes are disposed both in landfills and spread on farmland. However, in Chile, $90 \%$ of biomass comes from industrial wood residues, the capacity factor 
is $63 \%$ and the ash is only landfilled. The higher ODP and POCP values are justified because the industrial wood residues have a higher economic value in Chile and, therefore, the impacts allocated to the residues are higher (15\%) than in the literature $(3 \%-5 \%)$ [33, 34]. The low ADP value is associated with the higher capacity factor in Chile. The lower FAETP and MAETP impacts are due to both the greater contribution of industrial wood residues (minimal use of softwood) and the higher capacity factor. The lower TETP in this study is due to the absence of farmland spreading as a way of using the ashes. According to the literature, chromium is the main element released to agricultural soil due to the use of ashes on land and represents about $86 \%$ of TETP for electricity from biomass $[59,60]$.

Solar PV has the largest ADP in comparison with all the technologies in Chile $(1,165 \mu \mathrm{g} \mathrm{Sb}$ eq. $/ \mathrm{kWh})$; however, the impact still falls below the minimum literature value $(1,800 \mu \mathrm{g})$. This is due to the location of the PV and the difference in solar irradiation. The location of most solar PV systems in the Chile is in the Atacama Desert, an area with one of the highest solar radiation in the world, leading to an unusually high capacity factor (>24\%). These conditions are more favourable than those in the literature and explain the lower ADP per $\mathrm{kWh}$, and also a lower value for the rest of the impacts compared with the literature ranges. Similar applies to wind power, for which most impacts are below the range. This is due to the much higher capacity factor in Chile $(27 \%)$ than in the literature $(8.6 \%-15 \%)$ [17, 57]. In the case of hydropower, Chile has also higher capacity factors for the reservoirs (43\%) and run-of-river plants $(60 \%)$ than those in the literature (24\% and 52\%, respectively) [43]. This, together with the recycling rates and the scaling of the infrastructure, explains the lower impacts from Chile's hydropower than the values reported in the literature.

\subsection{Environmental impacts of current electricity mix}

The impacts of the electricity mix in Chile are presented in Figure 5. These have been estimated based on the contribution of different technologies to the total generation and their impacts discussed in the previous sections. For example, the GWP is estimated at $560 \mathrm{~g} \mathrm{CO}_{2}$ eq./kWh, with the majority related to coal. A similar trend can be noticed for all other impacts, for which coal is the hotspot. Its average contribution to the impacts is $79 \%$, with contributions of $>88 \%$ for HTP, AP, EP and ecotoxicities. ADP is the only impact where the contribution from coal $(38 \%)$ is lower than its share in the electricity mix (41\%).

The second highest contributor to the impacts is oil power, with an average of $8 \%$, while its share in the electricity mix is only $4 \%$. Oil has the highest contribution to ODP (39\%) and ADP (15\%). Natural gas also contributes to GWP (17\%) and $\mathrm{ADP}_{\text {fossil }}(21 \%)$, higher than its share in the generation mix $(14 \%)$.

Although solar power contributes to the electricity mix by less than $1 \%$, its contribution to $\mathrm{ADP}$ is $23 \%$. However, for the rest of the impacts, solar power has a lower contribution than its share in the mix. On the other hand, hydropower is the second major source of electricity (34\%), but its average contribution to the impacts is below $1 \%$. The contribution of biomass, wind and solar PV to the impacts is also far below their contribution to electricity generation. 


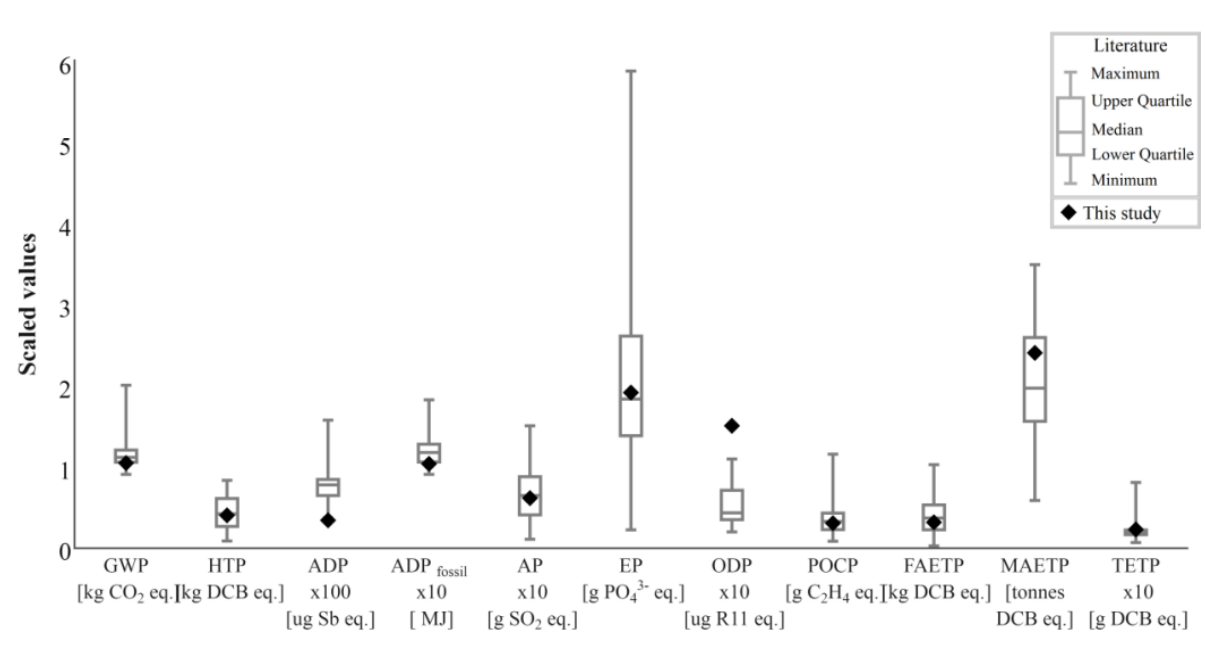

a) Coal

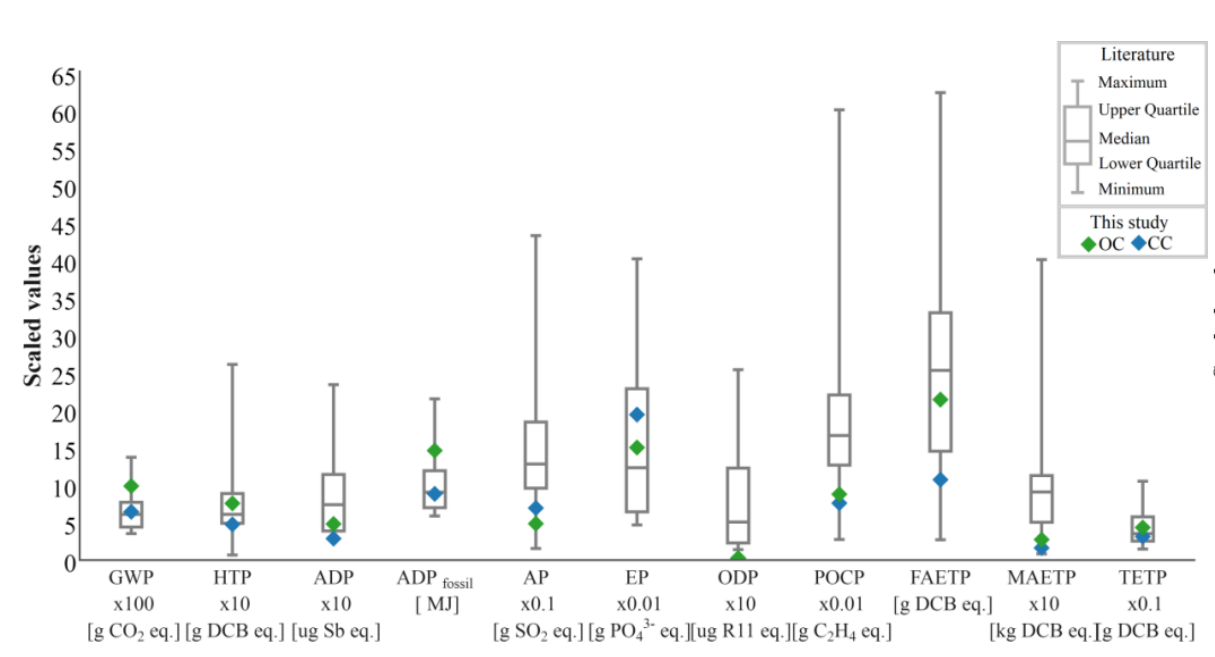

(c) Gas

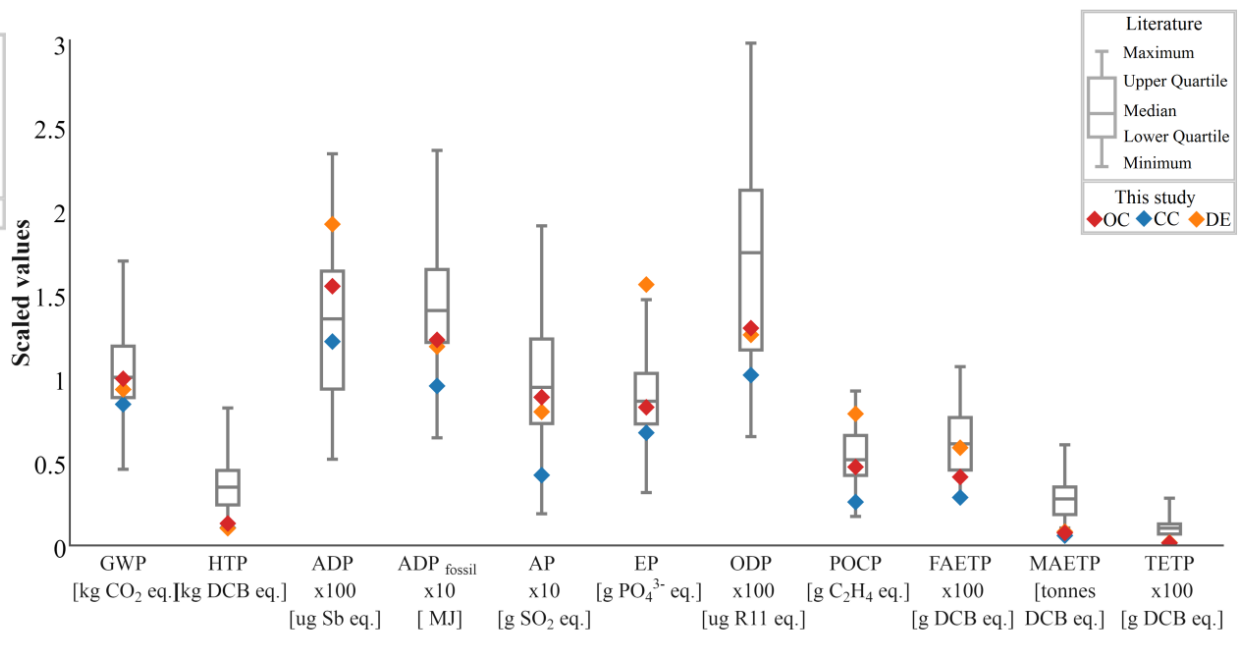

(b) Oil

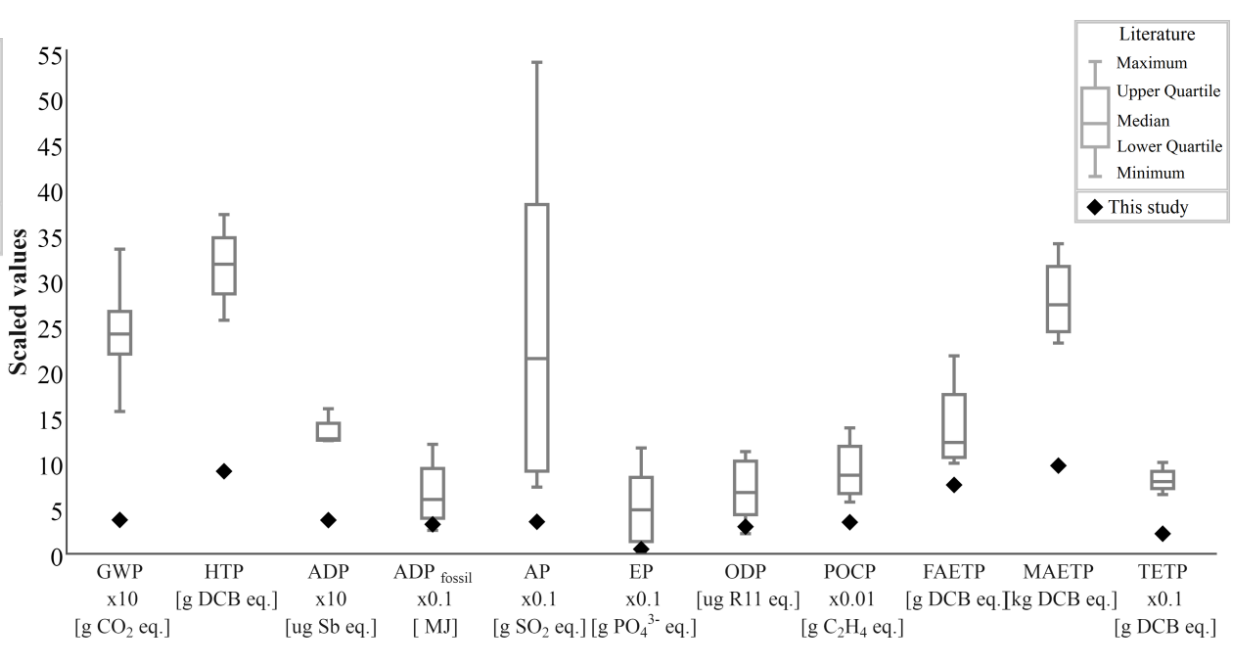

(d) Biogas 

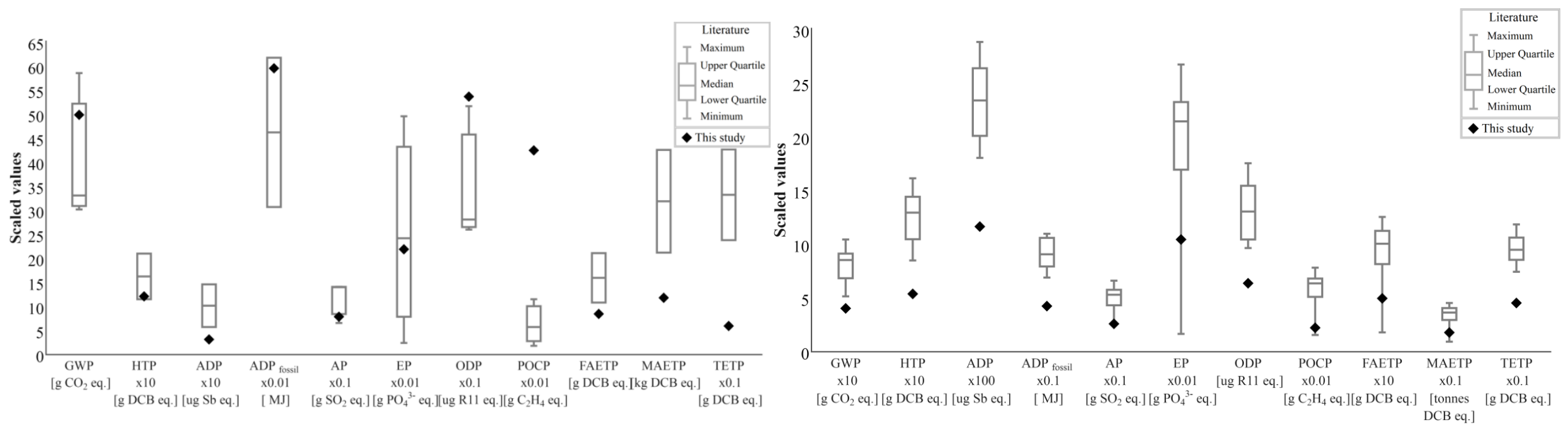

(e) Biomass

(f) Solar photovoltaics
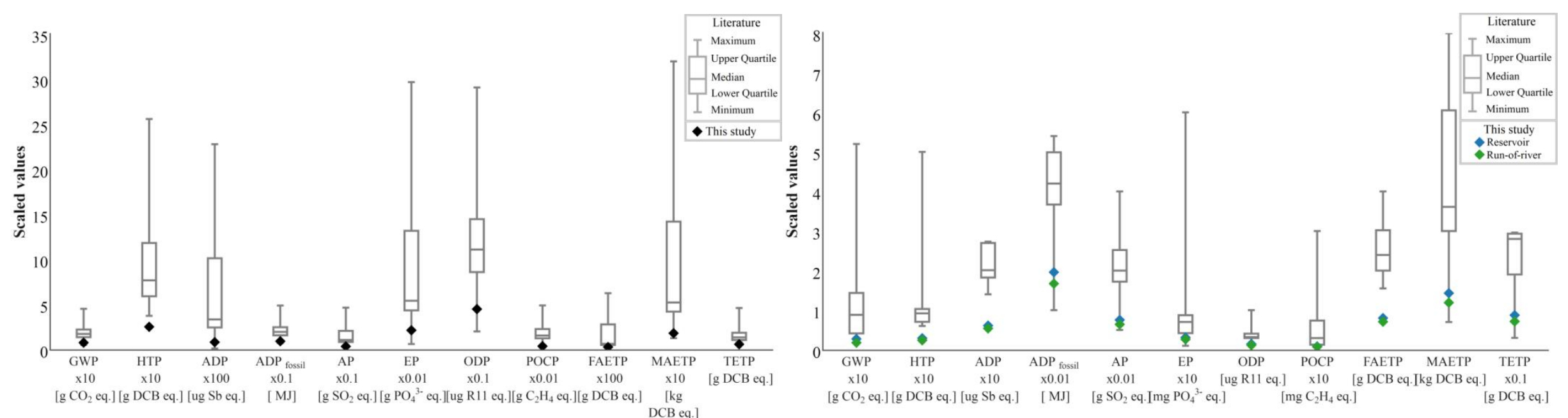

(g) Wind

(h) Hydropower

Figure 4. Comparison of environmental impacts of electricity options with the literature.

[All impacts expressed per kWh of electricity generated. Literature data: [14, 16-19, 21, 23, 35, 53]. Some impacts have been scaled to fit on the scale. To obtain the original values, multiply by the factor shown on the x-axis. OC: open cycle. CC: combined cycle. DE: diesel engine.] 


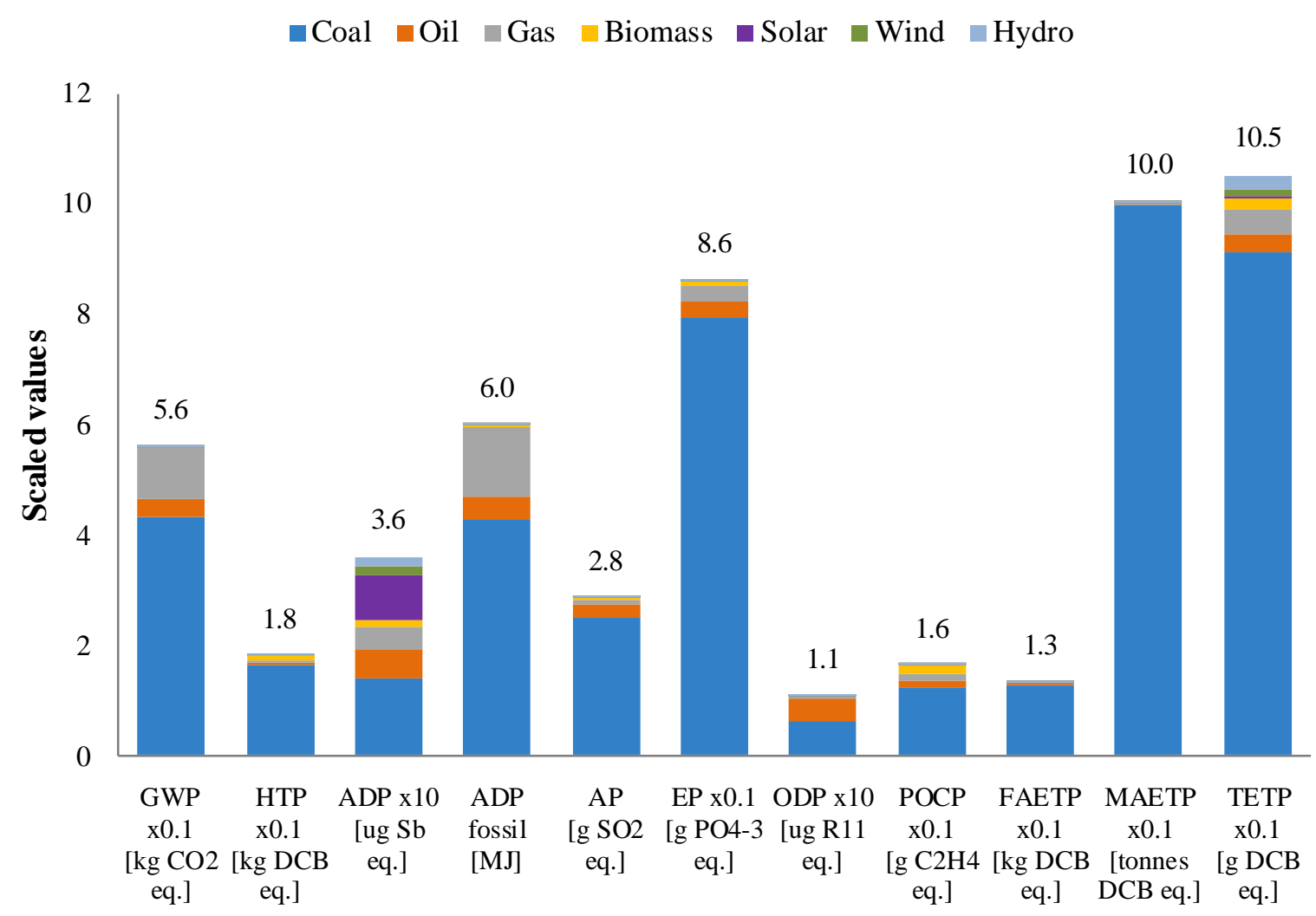

Figure 5. Life cycle environmental impacts of current electricity mix, showing contribution of different sources. [All impacts expressed per kWh. Some impacts have been scaled to fit on the scale. To obtain the original values, multiply by the factor shown on the $\mathrm{x}$-axis.]

\subsubsection{Comparison of results with literature}

The impacts of the electricity mix in Chile are compared in Figure 6 with the impacts reported in the literature $[14,16-18,21]$ for some other countries with similar electricity profiles (see Figure S1). It can be seen that most of the impacts are within the range. However, EP ( $860 \mathrm{mg}$ $\left.\mathrm{PO}_{4}{ }^{3-} \mathrm{eq} . / \mathrm{kWh}\right)$ and MAETP $(1,000 \mathrm{~kg}$ DCB eq. $/ \mathrm{kWh})$ are above the median literature values (534 mg $\mathrm{PO}_{4}{ }^{3-}$ eq. and $590 \mathrm{~kg}$ DCB eq., respectively). This is due to these two impacts being caused mainly by coal (>92\%; Figure 5) and its contribution to the electricity mix in Chile is higher (41\%) than in the selected countries (17\% on average). Furthermore, ADP (36 $\mu \mathrm{g} \mathrm{Sb}$ eq. $/ \mathrm{kWh})$ is below the literature median value $(67 \mu \mathrm{g} \mathrm{Sb}$ eq.). The ADP is associated with solar and oil power, which contribute only $4.6 \%$ to electricity in Chile, while their median contribution in the other countries considered is $8 \%$. Besides, coal has an ADP of $33 \mu \mathrm{g} \mathrm{Sb}$ eq./kWh, which is in the lower range of the values found in the literature (see section 3.1.10) and the hydropower options have a high contribution to the mix and very low ADP (5-6 $\mu \mathrm{g} \mathrm{Sb}$ eq./kWh). Finally, the ODP in Chile (11 $\mu \mathrm{g}$ R11 eq.) is also below the literature median (25 $\mu \mathrm{g}$ R11 eq.) because natural gas and solar PV in the other countries have higher ODP due to the distribution of natural gas through pipelines and a lower solar irradiation, respectively. 


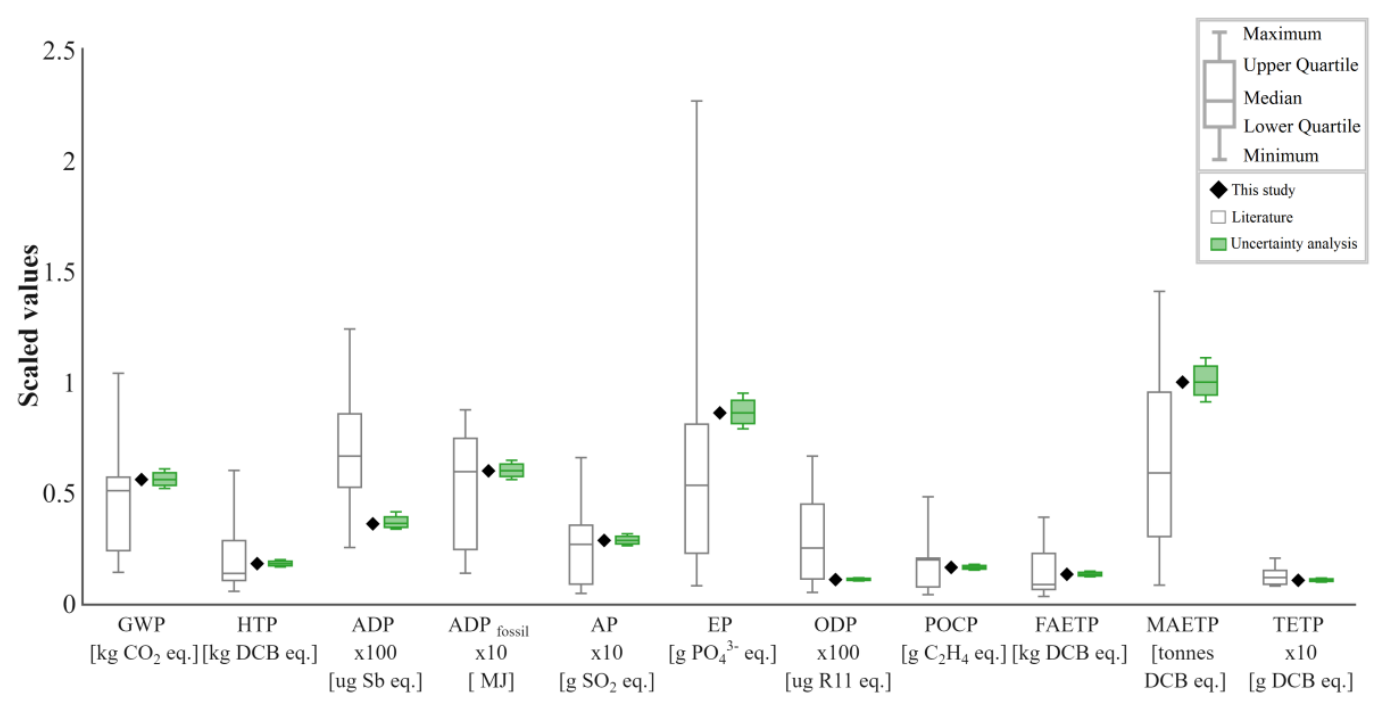

Figure 6. Comparison of environmental impacts of the electricity mix with the literature, also showing the results of the uncertainty analysis.

[All impacts expressed per kWh of electricity generated. Literature data: [14, 16-18, 21]. Some impacts have been scaled to fit on the scale. To obtain the original values, multiply by the factor shown on the $\mathrm{x}$-axis.]

\subsubsection{Uncertainty analysis}

The analysis so far has been based on the average values of around 140 LCA parameters obtained from power plants and grouped according to technology and source of energy. Each parameter considered represents a mean value in its group, estimated using normal distribution. An uncertainty analysis has been carried out using Monte Carlo (MC) simulations to test the reliability of the results based on the mean values of the parameters. For these purposes, the parameters have been varied in $\mathrm{MC}$ within their standard deviations (SD), estimated using the aforementioned normal distribution. As it would be impractical to consider all the parameters, first a sensitivity analysis has been carried out to identify those that are likely to contribute to the uncertainty the most. The sensitivity analysis has been carried for over 30 parameters, which have been selected based on their contribution to one or more impacts. The results indicate that only four parameters have a significant influence on the results. These have then been varied within their SD ranges in 10,000 MC iterations with $90 \%$ confidence intervals, as follows:

- efficiency of coal power plants: $\mathrm{SD}= \pm 7.9 \%$;

- $\mathrm{SO}_{2}$ emissions from coal plants: $\mathrm{SD}= \pm 3.7 \%$;

- efficiency of combined cycle oil power plants: $\mathrm{SD}= \pm 6.9 \%$; and

- capacity factor of solar PV: $\mathrm{SD}= \pm 30 \%$.

The results of the MC simulations are given in Figure 6 and Figure 7. The box plots in these figures represent the interquartile ranges and the whisker bars are the dispersion ranges between the $10^{\text {th }}$ and $90^{\text {th }}$ percentile. It can be seen that all the impacts except ADP deviate from their median value by $\leq 11 \%$, with the ADP deviating by $14 \%$. The latter is due to the high contribution of solar PV and oil power to the depletion of resources (see section 3.1.3) and their variations in the capacity factor (PV) and the efficiency of power plants (oil). The next highest variation is found for AP, MAETP and FAETP (11\%) which is mostly associated with the variation in the efficiency of coal power plants. Therefore, the results can be considered robust over the range of values of key parameters. 


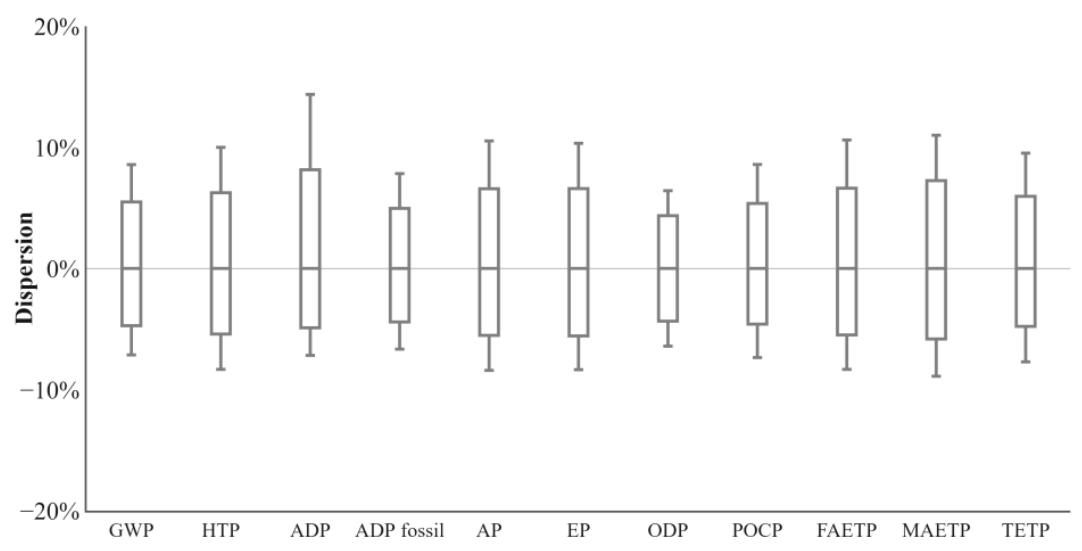

Figure 7. Results of the uncertainty analysis for the electricity mix in 2014 showing dispersion of the results relative to the baseline

[The box plots represent the interquartile ranges and the whiskers the dispersion ranges between the $10^{\text {th }}$ and $90^{\text {th }}$ percentile].

3.3. Temporal evolution of impacts

As indicated in Figure 8, all the impacts but ODP increased by 1.6-2.7 times from 2004 to 2014; GWP doubled. This is much higher than the increase in electricity generation of $44 \%$ over the period. The increase in the impacts is due to the growing share of coal in the electricity mix over the period (Table 8), which is also reflected in the increasing contribution of coal to the overall impacts. In 2014, it contributed more than $70 \%$ to the majority of impacts, with the exceptions of $\operatorname{ADP}(38 \%)$ and ODP (57\%).

On the other hand, ODP first increased by 2.4 times in 2009 and then decreased by 2.7 times in 2014, effectively being $12.5 \%$ lower now than in 2004. The reason for this is the high contribution of natural gas from Argentina in 2004 transported by long-distance pipelines and the use of petcoke in coal power plants. The contribution of the latter decreased from $26 \%$ in 2004 to $5.3 \%$ in 2014. A further reason for high ODP is that the share of oil peaked in 2009, producing $18 \%$ of electricity (Table 8 ) and being the second major contributor (after coal) to all the impacts in that year. However, electricity generation from oil has been declining since and in 2014 it contributed only $3.9 \%$, in consequence reducing its relative contribution to the impacts. By contrast, the contribution of natural gas is only notable for GWP and $\mathrm{ADP}_{\text {fossil }}$, especially in 2004 , when $36 \%$ of the electricity was generated from gas, compared to $14.3 \%$ in 2014.

Despite hydropower historically having a high share in the electricity mix (34\%-43.5\%), its contribution to the impacts over time has been negligible. The contribution of the other renewables is also negligible - while in the previous years, this was due to their minute share in the mix ( $<2 \%$ of biomass), this grew to a cumulative supply of $7 \%$ of electricity in 2014 . The renewables only have a significant contribution to ADP, mainly due to solar PV (see section 3.1.3). 


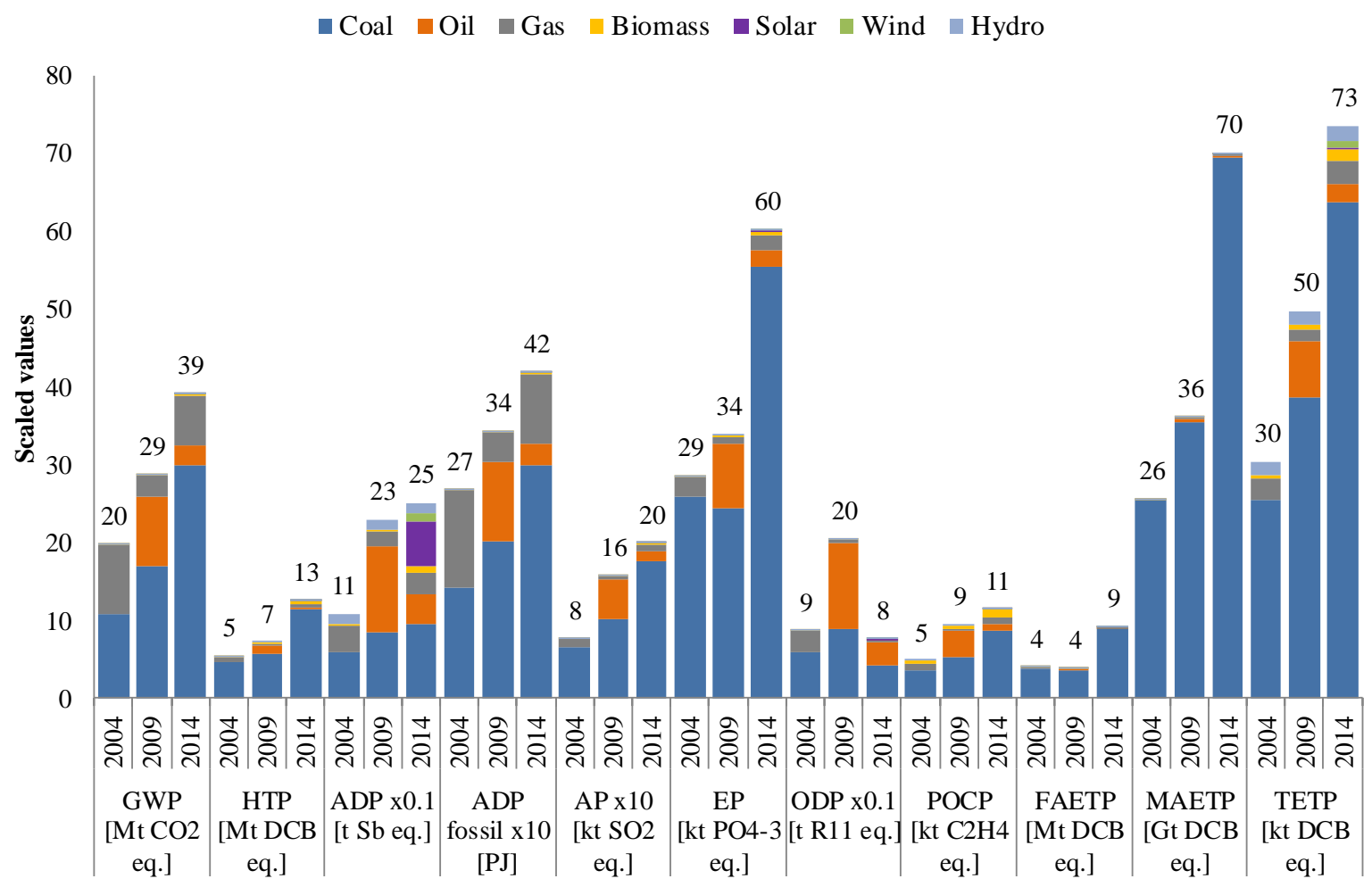

Figure 8. Total annual environmental impacts for years 2004, 2009 and 2014.

[All impacts expressed per year. Some impacts have been scaled to fit on the scale. To obtain the original values, multiply by the factor shown on the $\mathrm{x}$-axis.]

\section{Conclusions and recommendations}

This paper has presented the first comprehensive evaluation of the life cycle environmental sustainability of electricity generation in Chile. Eleven environmental impacts have been estimated, considering 174 power plants installed across the country. The results reveal that coal is the worst option for eight impacts while hydropower is the best alternative for all the categories, with run-of-river being slightly better than reservoirs. Biogas and wind follow hydropower closely. However, natural gas has lower impacts than biomass, wind and solar PV for several categories. Biomass power has at least twice the human toxicity and 12 times greater potential for creation of photochemical oxidants compared with the nearest renewable option and has similar values to fossil fuel options. Solar PV has the highest resources depletion, six times larger than the closest option, and the second largest marine aquatic ecotoxicity.

Coal power is the worst option for global warming, eutrophication and ecotoxicity and also has high values for depletion of fossil fuels, photochemical oxidants and acidification. Its ozone depletion is high due to the use of petroleum coke as a secondary fuel. On the other hand, ozone depletion for natural gas is low because the gas is supplied in a liquefied form, avoiding the use of long-distance pipelines.

The most impacting life cycle stages are fuel production and power plant operation, each contributing on average $40 \%$ to the total impacts of fossil-based, biogas and biomass options. For the rest of the renewables, power plant construction is the most significant stage with an average contribution of around $90 \%$. 
The significant contribution of coal in Chile's electricity mix $(41 \%)$ is the reason for its high contribution to the impacts, causing more than $88 \%$ of human toxicity, ecotoxicities, eutrophication and acidification. Additionally, although solar PV contributes less than $1 \%$ to the electricity mix, it is responsible for $23 \%$ of the depletion of elements per unit of electricity generated.

The environmental sustainability of the electricity supply in Chile has worsened over the past 10 years. Although the electricity demand grew by $44 \%$ over the period, the annual impacts increased by 1.6-2.7 times. The only exception is ozone depletion which in 2014 was $12.5 \%$ lower than ten years before.

Based on the results of this work, the following improvements could be pursued to improve the environmental sustainability of the electricity system in Chile. In the short term:

- To reduce the impacts from coal electricity, the efficiency of power plants should be increased.

- The efficiency of biomass plants should also be improved, along with using lowemissions machinery and vehicles.

- Legislation for fossil-fuel and biomass plants should be tightened to reduce emissions of $\mathrm{SO}_{2}, \mathrm{NO}_{\mathrm{x}}$, polycyclic aromatic hydrocarbons and hydrogen fluoride as well as to stipulate safe disposal of ash.

- Oil electricity currently used for peak loads should be replaced by a cleaner alternative, such as natural gas.

- The use of petcoke should be phased out.

In the medium to long term, the following should be considered:

- The share of renewables in the electricity supply should be ramped up while coal and oil should be phased out. In particular, hydropower, wind and biogas should be prioritised, Other emerging options, such as geothermal, should also be investigated. Any negative social impacts from these technologies should be minimised.

- Multi-crystalline solar PV depletes a significant amount of scarce materials. Hence, other solar alternatives should be considered, such as thin-film PV cells and concentrating solar power. The commercialisation of advanced PV panel recycling techniques should also be prioritised.

- Implementation of carbon capture and storage systems should be evaluated for both fossil and biomass options to mitigate carbon emissions.

Finally, future research should focus on the economic and social sustainability of the current electricity system as well as on the evaluation of the above-mentioned improvement options to ensure the sustainable development of the future electricity sector in Chile.

\section{Acknowledgements}

The authors thank the Chilean Government for awarding Carlos Gaete-Morales the scholarship "Becas Chile" for his doctoral study at the University of Manchester. The authors are also grateful to Dr Harish Jeswani at the University of Manchester for his help with the uncertainty analysis.

\section{Appendix A. Supplementary data}

The Supporting information includes data on biogas, biomass, hydropower plants and wind farms in Chile and the comparison of environmental impacts calculated for fossil fuel sources by the current study and the literature. 


\section{References}

1. Ministerio de Energía del Gobierno de Chile. (2014). Energy Agenda: A challenge for the country, progress for everyone.

2. Comisión Nacional de Energía de Chile. (2015). Database of electricity generation in Chile. Retrieved May 5, 2015, from https://www.cne.cl/estadisticas/electricidad/

3. Sims, D. (2011). Chile's clean energy future. Natural Resources Defense Council.

4. Ministerio de Medio Ambiente del Gobierno de Chile. (2014). Plan nacional de adaptación al cambio climático.

5. International Energy Agency. (2009). Chile energy policy review.

6. García, C. (2012). Impacto del costo de la energía eléctrica en la economía chilena : Una perspectiva macroeconómica. Facultad de Economía y Negocios Universidad Alberto Hurtado.

7. Instituto Nacional de Derechos Humanos de Chile. (2012). Mapa de conflictos socioambientales en Chile.

8. Ministerio de Energía del Gobierno de Chile. (2015). Estudio de Cuencas - Resumen Ejecutivo.

9. PRIEN-UTFSM. (2008). Aporte potencial de energías renovables no convencionales y eficiencia energética a la matriz electrica 2008 - 2025.

10. Norton Rose Fulbright. (2016). Renewable Energy in Latin America.

11. Santana, C., Falvey, M., Ibarra, M., \& García, M. (2014). Energías renovables en Chile. El potencial eólico, solar e hidroeléctrico de Arica a Chiloé. Ministerio de Energía del Gobierno de Chile and GIZ. Santiago, Chile.

12. Ministerio de Energía del Gobierno de Chile. (2015). Hoja de ruta 2050: Hacia una energia sustentable e inclusiva para Chile.

13. Ministerio de Energía del Gobierno de Chile. (2015). Energy 2050: Chile's energy policy.

14. Santoyo-Castelazo, E., Gujba, H., \& Azapagic, A. (2011). Life cycle assessment of electricity generation in Mexico. Energy, 36(3), 1488-1499. doi:10.1016/j.energy.2011.01.018

15. Gujba, H., Mulugetta, Y., \& Azapagic, A. (2011). Power generation scenarios for Nigeria: An environmental and cost assessment. Energy Policy, 39(2), 968-980. doi:10.1016/j.enpol.2010.11.024

16. Atilgan, B., \& Azapagic, A. (2016). Assessing the environmental sustainability of electricity generation in Turkey on a life cycle basis. Energies, 9(1), 31. doi:10.3390/en9010031

17. Stamford, L., \& Azapagic, A. (2012). Life cycle sustainability assessment of electricity options for the UK. International Journal of Energy Research, 36(14), 1263-1290. doi:10.1002/er.2962

18. Garcia, R., Marques, P., \& Freire, F. (2014). Life-cycle assessment of electricity in Portugal. Applied Energy, 134, 563-572. doi:10.1016/j.apenergy.2014.08.067

19. Coltro, L., Garcia, E., \& Queiroz, G. (2003). Life cycle inventory for electric energy system in Brazil. The International Journal of Life Cycle Assessment, 8(5), 290-296. doi:10.1065/lca2003.08.131

20. CCaLC. (2016). CCaLC2 software and database. The University of Manchester. Retrieved from www.ccalc.org.uk

21. Ecoinvent. (2010). Database V2.2. Swiss Centre for Life cycle Inventories.

22. PE International. (2015). Life cycle assessment software (GaBi) Version 7.

23. Itten, R., Frischknecht, R., \& Stucki, M. (2014). Life cycle inventories of electricity mixes and grid. treeze Ltd. Uster, Switzerland.

24. International Organization for Standardization. ISO 14040 - Environmental 
management - Life cycle assessment - Principles and framework (2006). Geneva, Switzerland.

25. International Organization for Standardization. ISO 14044 - Environmental management - Life cycle assessment - Requirements and guidelines (2006). Geneva, Switzerland.

26. Centro de Despacho Económico de Carga. (2016). Updated database. Sistema Eléctrico Nacional. Retrieved May 5, 2016, from https://www.coordinador.cl/informes-ydocumentos/

27. Superintendencia del Medioambiente de Chile (SMA). (2015). Data record of emissions and fuel composition for Chilean thermal power plants. Santiago, Chile.

28. waste-management-world.com. (2012, April 30). 8.4 MW upgrade to biogas power facility at Chile's largest landfill. Press release.

29. Servicio de Evaluación Ambiental. (2015). Sistema de evaluación de impacto ambiental (SEIA). Retrieved December 3, 2016, from http://www.sea.gob.cl/

30. Boschiero, M., Kelderer, M., Schmitt, A. O., Andreotti, C., \& Zerbe, S. (2015). Influence of agricultural residues interpretation and allocation procedures on the environmental performance of bioelectricity production - A case study on woodchips from apple orchards. Applied Energy, 147, 235-245. doi:10.1016/j.apenergy.2015.01.109

31. International Institute for Sustainability Analysis and Strategy. (2015). Global emissions model for integrated systems (GEMIS).

32. Giménez, A., Puyuelo, B., Rodríguez, L., \& Castaño, J. (2013). Antecentes del aprovechamiento energético de la fracción biodegradable de los residuos sólidos domiciliarios y no domiciliarios. Ministerio de Energia del Gobierno de Chile.

33. Althaus, H., Dinkel, F., Stettler, C., \& Werner, F. (2007). Life cycle inventories of renewable materials. Final report ecoinvent data v2.0 No. 21. EMPA, Swiss Centre for Life Cycle Inventories. Dübendorf, $\mathrm{CH}$.

34. Werner, F., Althaus, H., Künniger, T., Richter, K., \& Jungbluth, N. (2007). Life cycle inventories of wood as fuel and construction material. Final report ecoinvent 2000 No. 9. EMPA Dübendorf, Swiss Centre for Life Cycle Inventories. Dübendorf, $\mathrm{CH}$.

35. Kouloumpis, V., Stamford, L., \& Azapagic, A. (2015). Decarbonising electricity supply: Is climate change mitigation going to be carried out at the expense of other environmental impacts? Sustainable Production and Consumption, 1(January), 1-21. doi:10.1016/j.spc.2015.04.001

36. SunPower Corporation. (2015). Fact Sheet: PV Salvador solar project.

37. Solar Pack. (2016). Pozo al Monte photovoltaic plants. Retrieved March 5, 2016, from https://www.solarpack.es/en/pais/chile-2/

38. Enel Green Power Spa. (2014). Enel Green Power: three new photovoltaic plants in Chile. Press release.

39. Yu, M., \& Halog, A. (2015). Solar photovoltaic development in Australia - A life cycle sustainability assessment study. Sustainability, 7(2), 1213-1247. doi:10.3390/su7021213

40. SunPower Corporation. (2016). Datasheet: Performance Series 1500 Volt.

41. Jordan, D., \& Kurtz, S. (2013). Photovoltaic degradation rates - An analytical review. Progress in Photovoltaics: Research and Applications, 21(1), 12-29. doi:10.1002/pip.1182

42. Turconi, R., Boldrin, A., \& Astrup, T. (2013). Life cycle assessment (LCA) of electricity generation technologies: Overview, comparability and limitations. Renewable and Sustainable Energy Reviews, 28, 555-565. doi:10.1016/j.rser.2013.08.013 
43. Bauer, C., Bolliger, R., Tuchschmid, M., \& Faist-Emmenegger, M. (2007). Wasserkraft. In R. Dones (Ed.), Sachbilanzen von Energiesystemen: Grundlagen für den ökologischen Vergleich von Energiesystemen und den Einbezug von Energiesystemen in Ökobilanzen für die Schweiz. ecoinvent report No. 6-VIII. Swiss Centre for Life Cycle Inventories. Dübendorf, $\mathrm{CH}$.

44. Sinnott, R. K. (2005). Design. Coulson \& Richardson's Chemical Engineering series Elsevier (Vol. 6). doi:10.1016/S1385-8497(00)00184-4

45. Greening, B., \& Azapagic, A. (2013). Environmental impacts of micro-wind turbines and their potential tocontribute to UK climate change targets. Energy, 59, 454-466. doi:10.1016/j.energy.2013.06.037

46. Guinée, J. B., Gorree, M., Heijungs, R., Huppes, G., Kleijn, R., de Koning, A., \& van Oers, L. (2002). Handbook on life cycle assessment. Operational guide to the ISO standards (Vol. 7). The Hague and Leiden, The Netherlands: Ministry of Housing, Spatial Planning and Environment (VROM) and Centre of environmental Science (CML). doi:10.1007/0-306-48055-7

47. Koffler, C. (2014). Best practice LCA: End-of-Life modelling.

48. European Aluminium Association. (2013). Aluminium recycling in LCA. Brussels, Belgium.

49. European Aluminium Association. (2013). Recycled Content vs. End-of-Life Recycling Rate. Brussels, Belgium.

50. Bergsma, G., \& Sevenster, M. (2013). End-of-life best approach for allocating recycling benefits in LCAs of metal packaging. CE Delft. Delft, The Netherlands.

51. Classen, M., Althaus, H.-J., Blaser, S., Tuchschmid, M., Jungbluth, N., Doka, G., ... Scharnhorst, W. (2009). Life cycle inventories of metals. Final report ecoinvent data v2.1, No 10. EMPA Dübendorf, Swiss Centre for Life Cycle Inventories. Dübendorf, $\mathrm{CH}$.

52. Ministerio de Energía del Gobierno de Chile. (2014). Energy Balance of Chile.

53. Whiting, A., \& Azapagic, A. (2014). Life cycle environmental impacts of generating electricity and heat from biogas produced by anaerobic digestion. Energy, 70, 181-193. doi:10.1016/j.energy.2014.03.103

54. Jungbluth, N., Chudacoff, M., Dauriat, A., Dinkel, F., Doka, G., Faist Emmenegger, M., ... Sutter, J. (2007). Life cycle inventories of bioenergy. ecoinvent report No. 17, Swiss Centre for Life Cycle Inventories. Dübendorf, $\mathrm{CH}$.

55. Mastral, A., \& Callen, M. (2000). A review on polycyclic aromatic hydrocarbon (PAH) Emissions from energy generation. Environmental Science \& Technology, 34(15), 3051-3057. doi:10.1021/es001028d

56. Jungbluth, N. (2007). Erdöl. In R. Dones (Ed.), Sachbilanzen von Energiesystemen: Grundlagen für den ökologischen Vergleich von Energiesystemen und den Einbezug von Energiesystemen in Ökobilanzen für die Schweiz. ecoinvent report No. 6-IV. Swiss Centre for Life Cycle Inventories. Dübendorf, $\mathrm{CH}$.

57. Jungbluth, N., Stucki, M., Flury, K., Frischknecht, R., \& Büsser, S. (2012). Life cycle inventories of photovoltaics. ESU-services Ltd. Uster, $\mathrm{CH}$.

58. UNEP Ozone Secretariat. (2010). Handbook for the Montreal protocol on substances that deplete the ozone layer, The Montreal protocol, Summary of control measures under the Montreal protocol, Annex A - Group II: Halons (Halon 1211, Halon 1301 and Halon 2402).

59. Dones, R., Bauer, C., Bolliger, R., Burger, B., Faist Emmenegger, M., Frischknecht, R., Tuchsmid, M. (2007). Life cycle inventories of energy systems: Results for current systems in Switzerland and other UCTE countries. ecoinvent report No. 5. Paul Scherrer Institut Villigen, Swiss Centre for Life Cycle Inventories. Dübendorf, CH. 
60. Bauer, C. (2007). Holzenergie. In R. Dones (Ed.), Sachbilanzen von Energiesystemen: Grundlagen für den ökologischen Vergleich von Energiesystemen und den Einbezug von Energiesystemen in Ökobilanzen für die Schweiz. ecoinvent report No. 6-IX. Swiss Centre for Life Cycle Inventories. Dübendorf, CH. 


\section{Assessing the environmental sustainability of electricity generation in Chile}

Carlos Gaete-Morales, Alejandro Gallego-Schmid, Laurence Stamford and Adisa Azapagic Supporting Information

Table S1. Biogas and biomass power plants in Chile in 2014[1-3]

\begin{tabular}{|c|c|c|c|c|c|}
\hline \multirow{2}{*}{$\begin{array}{l}\text { Fuel } \\
\text { type } \\
\text { Biogas }\end{array}$} & \multirow{2}{*}{$\begin{array}{l}\text { Power plant } \\
\text { 1 Loma Los Colorados II }\end{array}$} & \multirow{2}{*}{$\begin{array}{r}\begin{array}{r}\text { Installed } \\
\text { capacity }\end{array} \\
\left(\mathbf{M W}_{\mathrm{e}}\right)\end{array}$} & \multirow{2}{*}{$\begin{array}{c}\begin{array}{c}\text { Electricity } \\
\text { generation } \\
\text { (GWh) }\end{array} \\
131\end{array}$} & \multicolumn{2}{|c|}{$\begin{array}{c}\text { Share by source } \\
(\%)\end{array}$} \\
\hline & & & & 83 & Landfill \\
\hline & 2 Loma Los Colorados & 2 & 3.5 & & \\
\hline & 3 Santa Marta & 14 & 100 & & \\
\hline & 4 Trebal Mapocho & 5 & 41 & 15 & Sludge sewage \\
\hline & 5 Santa Irene & 0.4 & 3 & 3 & Manure and \\
\hline & $6 \mathrm{HBS}$ & 2 & 3 & & organic waste \\
\hline & 7 Las Pampas & 0.4 & 1 & & \\
\hline & 8 Tamm & 0.2 & 0.3 & & \\
\hline Biomass & 1 Santa Fe & 67 & 476 & 90 & Industrial \\
\hline & 2 Valdivia $^{\mathrm{a}}$ & 61 & 326 & & residual wood \\
\hline & 3 Nueva Aldea III ${ }^{\mathrm{b}}$ & 37 & 275 & & \\
\hline & 4 Viñales & 22 & 179 & & \\
\hline & 5 CMPC Pacífico & 33 & 176 & & \\
\hline & 6 Energía Pacífico & 16 & 105 & & \\
\hline & 7 Escuadrón & 14 & 89 & & \\
\hline & 8 Arauco & 24 & 87 & & \\
\hline & 9 CMPC Laja ${ }^{\text {b }}$ & 25 & 84 & & \\
\hline & 10 Nueva Aldea I & 19 & 83 & & \\
\hline & 11 Cholguán & 13 & 75 & & \\
\hline & 12 Cabrero & 11 & 55 & & \\
\hline & 13 Licantén $^{\mathrm{a}}$ & 6 & 45 & & \\
\hline & 14 Energía BíoBío & 7 & 41 & & \\
\hline & 15 Laja & 13 & 40 & & \\
\hline & 16 Constitución & 8 & 30 & & \\
\hline & 17 Energía León & 7 & 22 & & \\
\hline & 18 Lautaro & 26 & 192 & 10 & Cereal straw \\
\hline & 19 Lautaro II & 22 & 51 & & \\
\hline
\end{tabular}

\footnotetext{
${ }^{\mathrm{a}}$ Plant only fed by black liquor.

${ }^{\mathrm{b}}$ Plant partially fed by black liquor.
} 
Table S2. Hydropower plants in Chile in 2014 [1-3].

\begin{tabular}{lllcc}
\hline $\begin{array}{l}\text { Technology } \\
\text { type }\end{array}$ & Power plant & $\begin{array}{c}\text { Installed } \\
\text { capacity }\left(\mathbf{M W}_{\mathrm{e}}\right)\end{array}$ & $\begin{array}{c}\text { Electricity } \\
\text { generation }(\mathbf{G W h})\end{array}$ \\
\hline Reservoir & 1 & Ralco & 690 & 2,621 \\
& 2 & Pehuenche & 570 & 2,276 \\
& 3 & Colbun & 474 & 1,962 \\
& 4 & Pangue & 467 & 1,840 \\
& 5 & El Toro & 450 & 947 \\
& 6 & Rapel & 378 & 481 \\
& 7 & Angostura & 324 & 1,300 \\
& 8 & Canutillar & 172 & 271 \\
& 9 & Cipreses & 106 & 431 \\
\hline & 10 & Machicura & 95 & 1,285 \\
& 1 & Antuco & 320 & 767 \\
& 2 & Rucúe & 178 & 696 \\
& 3 & Alfalfal & 178 & 376 \\
& 4 & La Confluencia & 163 & 461 \\
& 5 & La Higuera & 155 & 259 \\
& 6 & Abanico & 136 & 448 \\
& 7 & Chacayes & 112 & 6,158 \\
\hline
\end{tabular}

Table S3. Wind farms and solar power plants in Chile in 2014 [1-3].

\begin{tabular}{|c|c|c|c|c|}
\hline $\begin{array}{l}\text { Technology } \\
\text { type }\end{array}$ & & Power plant & $\begin{array}{c}\text { Installed capacity } \\
\left(\mathrm{MW}_{\mathrm{e}}\right)\end{array}$ & $\begin{array}{c}\text { Electricity generation } \\
(\text { GWh })\end{array}$ \\
\hline \multirow[t]{16}{*}{ Wind } & 1 & Canela & 18 & 27 \\
\hline & 2 & Canela II & 60 & 130 \\
\hline & 3 & Eólica Cuel & 33 & 94 \\
\hline & 4 & Eólica El Arrayán & 115 & 184 \\
\hline & 5 & Eólica Los Cururos & 110 & 149 \\
\hline & 6 & Eólica Punta Palmeras & 45 & 28 \\
\hline & 7 & Eólica San Pedro & 36 & 78 \\
\hline & 8 & Eólica Taltal & 99 & 30 \\
\hline & 9 & Lebu & 4 & 14 \\
\hline & 10 & Monte Redondo & 48 & 110 \\
\hline & 11 & Punta Colorada & 20 & 21 \\
\hline & 12 & Talinay & 90 & 229 \\
\hline & 13 & Totoral & 46 & 89 \\
\hline & 14 & Ucuquer 1 & 7 & 19 \\
\hline & 15 & Ucuquer 2 & 11 & 8 \\
\hline & 16 & Valle de los Vientos & 90 & 215 \\
\hline \multirow[t]{19}{*}{ Solar } & 1 & Chañares & 35 & 2 \\
\hline & 2 & La Huayca SPS-1 & 1 & 11 \\
\hline & 3 & Los Puquios & 3 & 4 \\
\hline & 4 & Maria Elena & 72 & 24 \\
\hline & 5 & Pozo Almonte Solar 2 & 8 & 15 \\
\hline & 6 & Pozo Almonte Solar 3 & 16 & 32 \\
\hline & 7 & Salvador & 68 & 6 \\
\hline & 8 & SDGx01 & 1 & 2 \\
\hline & 9 & Solar Diego de Almagro & 30 & 26 \\
\hline & 10 & Solar El Aguila & 2 & 4 \\
\hline & 11 & Solar Esperanza & 3 & 5 \\
\hline & 12 & Solar Hornitos & 0 & 0 \\
\hline & 13 & Solar Las Terrazas & 2 & 1 \\
\hline & 14 & Solar Llano de Llampos & 101 & 219 \\
\hline & 15 & Solar PSF Lomas Coloradas & 2 & 2 \\
\hline & 16 & Solar PSF Pama & 2 & 2 \\
\hline & 17 & Solar San Andrés & 51 & 99 \\
\hline & 18 & Solar Santa Cecilia & 3 & 6 \\
\hline & 19 & Tambo Real & 1 & 4 \\
\hline
\end{tabular}


Table S4. Life cycle inventory for coal and natural gas plants in 2004, 2009 and $2014^{\mathrm{a}}$ [1-4].

\begin{tabular}{|c|c|c|c|c|}
\hline & 2004 & 2009 & 2014 & Unit and description \\
\hline \multicolumn{5}{|l|}{ Coal } \\
\hline \multirow[t]{8}{*}{ Power plant } & 35 & 36 & $36 \%$ & [\%] Efficiency \\
\hline & $\mathbf{5 0}$ & 85 & 81 & [\%] Capacity factor \\
\hline & 38 & 38 & 38 & [yr] Lifespan \\
\hline & 97.5 & 97.5 & 97.5 & {$[\mathrm{~g} / \mathrm{MJ}]$ Direct emission of $\mathrm{CO}_{2}$} \\
\hline & 167 & 167 & 167 & {$[\mathrm{mg} / \mathrm{MJ}]$ Direct emission of $\mathrm{NO}_{\mathrm{x}}$} \\
\hline & 337 & 337 & 337 & {$[\mathrm{mg} / \mathrm{MJ}]$ Direct emission of $\mathrm{SO}_{2}$} \\
\hline & 82 & 82 & 82 & {$[\mathrm{mg} / \mathrm{MJ}]$ Retention of $\mathrm{NO}_{\mathrm{x}}$} \\
\hline & 205 & 205 & 205 & {$[\mathrm{mg} / \mathrm{MJ}]$ Retention of $\mathrm{SO}_{2}$} \\
\hline \multirow[t]{5}{*}{ Fuel transport } & 11959 & 11959 & 11959 & {$[\mathrm{~km}]$ Distance of coal shipment from Australia } \\
\hline & 3220 & 3220 & 3220 & {$[\mathrm{~km}]$ Distance of coal shipment from Chile } \\
\hline & 4585 & 4585 & 4585 & {$[\mathrm{~km}]$ Distance of coal shipment from Colombia } \\
\hline & 11959 & 11959 & - & {$[\mathrm{km}]$ Distance of coal shipment from Indonesia } \\
\hline & 8785 & 8785 & 8785 & {$[\mathrm{~km}]$ Distance of coal and petcoke shipment from USA } \\
\hline \multirow{7}{*}{$\begin{array}{l}\text { Fuel } \\
\text { contribution }\end{array}$} & $25 \%$ & $1 \%$ & $8 \%$ & [\%]Australia coal contribution to total coal and petcoke consumption \\
\hline & $4 \%$ & $6 \%$ & $10 \%$ & [\%] Chilean coal contribution to total coal and petcoke consumption \\
\hline & $13 \%$ & $\mathbf{5 0 \%}$ & $54 \%$ & [\%] Colombian coal contribution to total coal and petcoke consumption \\
\hline & $17 \%$ & $\mathbf{8 \%}$ & $\mathbf{0 \%}$ & [\%] Indonesia coal contribution to total coal and petcoke consumption \\
\hline & $17 \%$ & $8 \%$ & $23 \%$ & [\%] USA coal contribution to total coal and petcoke consumption \\
\hline & $5 \%$ & $18 \%$ & $2 \%$ & [\%] Chilean petcoke contribution to total coal and petcoke consumption \\
\hline & $19 \%$ & $8 \%$ & $3 \%$ & [\%] USA petcoke contribution to total coal and petcoke consumption \\
\hline \multirow[t]{6}{*}{ Heating value } & 21.0 & 25.0 & 27.0 & {$[\mathrm{MJ} / \mathrm{kg}]$ Higher heating value of coal in Australia } \\
\hline & 18.9 & 18.9 & 18.9 & [MJ/kg] Higher heating value of coal in Chile \\
\hline & 21.0 & 25.0 & 26.8 & {$[\mathrm{MJ} / \mathrm{kg}]$ Higher heating value of coal in Colombia } \\
\hline & 21.0 & 25.0 & 20.7 & {$[\mathrm{MJ} / \mathrm{kg}]$ Higher heating value of coal in Indonesia } \\
\hline & 21.0 & 25.0 & 26.0 & {$[\mathrm{MJ} / \mathrm{kg}]$ Higher heating value of coal in USA } \\
\hline & 32.5 & 32.5 & 32.5 & {$[\mathrm{MJ} / \mathrm{kg}]$ Higher heating value of petcoke in Chile and USA } \\
\hline \multicolumn{5}{|l|}{ Natural gas } \\
\hline \multirow{2}{*}{$\begin{array}{l}\text { Technology } \\
\text { contribution }\end{array}$} & 100 & 100 & 96 & [\%] Combined cycle power plant share of total electricity from natural gas \\
\hline & $\mathbf{0}$ & $\mathbf{0}$ & 4 & [\%] Open cycle power plant share of total electricity from natural gas \\
\hline \multirow{6}{*}{$\begin{array}{l}\text { Combined } \\
\text { cycle power } \\
\text { plant }\end{array}$} & 47 & 48 & 47 & {$[\%]$ Efficiency } \\
\hline & 65 & 17 & 53 & [\%] Capacity factor \\
\hline & 35 & 45 & 35 & [yr] Lifespan \\
\hline & 61.9 & 61.9 & 61.9 & {$[\mathrm{~g} / \mathrm{MJ}]$ Direct emission of $\mathrm{CO}_{2}$} \\
\hline & 129 & 129 & 129 & {$[\mathrm{mg} / \mathrm{MJ}]$ Direct emission of $\mathrm{NO}_{\mathrm{x}}$} \\
\hline & 0.65 & 0.65 & 0.65 & {$[\mathrm{mg} / \mathrm{MJ}]$ Direct emission of $\mathrm{SO}_{2}$} \\
\hline \multirow{6}{*}{$\begin{array}{l}\text { Open cycle } \\
\text { power plant }\end{array}$} & - & - & 28 & {$[\%]$ Efficiency } \\
\hline & - & - & 11 & [\%] Capacity factor \\
\hline & - & - & 45 & [yr] Lifespan \\
\hline & - & - & 56 & [g/MJ] Direct emission of $\mathrm{CO}_{2}$ \\
\hline & - & - & 25 & {$[\mathrm{mg} / \mathrm{MJ}]$ Direct emission of $\mathrm{NO}_{\mathrm{x}}$} \\
\hline & - & - & 0.73 & {$[\mathrm{mg} / \mathrm{MJ}]$ Direct emission of $\mathrm{SO}_{2}$} \\
\hline \multirow{2}{*}{$\begin{array}{l}\text { Gas } \\
\text { distribution }\end{array}$} & 39.1 & 39.9 & 41.1 & {$\left[\mathrm{MJ} / \mathrm{Nm}^{3}\right]$ Higher heating value of natural gas } \\
\hline & $1.53 \times 10^{-7}$ & $1.53 \times 10^{-7}$ & $1.53 \times 10^{-7}$ & {$[\mathrm{~m} / \mathrm{MJ}]$ Gas network. Estimated from gas sales and total length of pipeline } \\
\hline \multirow{2}{*}{$\begin{array}{l}\text { Regasification } \\
\text { plant }\end{array}$} & $3.04 \times 10^{-12}$ & $3.04 \times 10^{-12}$ & $3.04 \times 10^{-12}$ & {$\left[\mathrm{Unit} / \mathrm{Nm}^{3}\right]$ Part of terminal per $\mathrm{Nm}^{3}$ of liquefied natural gas $(\mathrm{LNG})$} \\
\hline & 2.25 & 2.25 & 2.25 & Scaling factor. Estimated from original size and actual size to the power of 0.6 \\
\hline \multirow{4}{*}{$\begin{array}{l}\text { Gas supply } \\
\text { and transport }\end{array}$} & $\mathbf{0}$ & 43 & 100 & {$[\%]$ LNG contribution to the gas mix } \\
\hline & 100 & 57 & $\mathbf{0}$ & [\%] Long-distance pipeline gas contribution to gas mix \\
\hline & - & 12,684 & 12,684 & {$[\mathrm{~km}]$ Distance of LNG tanker route from exporting countries } \\
\hline & 558 & 558 & - & {$[\mathrm{km}]$ Long-distance pipeline from export country } \\
\hline
\end{tabular}

\footnotetext{
${ }^{\mathrm{a}}$ Parameters in bold vary through the years.
} 
Table S5. Life cycle inventory for oil plants in 2004, 2009 and $2014^{\mathrm{a}}$ [1-4].

\begin{tabular}{|c|c|c|c|c|}
\hline & 2004 & 2009 & 2014 & Description \\
\hline \multicolumn{5}{|l|}{ Oil } \\
\hline \multirow{3}{*}{$\begin{array}{l}\text { Technology } \\
\text { contribution }\end{array}$} & - & 81 & 73 & [\%] Combined cycle power plant share of total electricity from oil \\
\hline & - & 10 & 14 & [\%] Open cycle power plant share of total electricity from oil \\
\hline & - & 9 & 13 & [\%] Diesel engine power plant share of total electricity from oil \\
\hline \multirow{6}{*}{$\begin{array}{l}\text { Combined } \\
\text { cycle power } \\
\text { plant }\end{array}$} & - & 44 & 44 & {$[\%]$ Efficiency } \\
\hline & - & 75 & 15 & [\%] Capacity factor \\
\hline & - & 35 & 45 & [yr] Lifespan \\
\hline & - & 89 & 89 & {$[\mathrm{~g} / \mathrm{MJ}]$ Direct emission of $\mathrm{CO}_{2}$} \\
\hline & - & 295 & 295 & {$[\mathrm{mg} / \mathrm{MJ}]$ Direct emission of $\mathrm{NO}_{\mathrm{x}}$} \\
\hline & - & 185 & 185 & {$[\mathrm{mg} / \mathrm{MJ}]$ Direct emission of $\mathrm{SO}_{2}$} \\
\hline \multirow{6}{*}{$\begin{array}{l}\text { Open cycle } \\
\text { power plant }\end{array}$} & - & 34 & 34 & [\%] Efficiency \\
\hline & - & 30 & 6 & [\%] Capacity factor \\
\hline & - & 35 & 45 & [yr] Lifespan \\
\hline & - & 80 & 80 & {$[\mathrm{~g} / \mathrm{MJ}]$ Direct emission of $\mathrm{CO}_{2}$} \\
\hline & - & 265 & 265 & {$[\mathrm{mg} / \mathrm{MJ}]$ Direct emission of $\mathrm{NO}_{\mathrm{x}}$} \\
\hline & - & 474 & 474 & {$[\mathrm{mg} / \mathrm{MJ}]$ Direct emission of $\mathrm{SO}_{2}$} \\
\hline \multirow{6}{*}{$\begin{array}{l}\text { Diesel engine } \\
\text { power plant }\end{array}$} & - & 36 & 36 & [\%] Efficiency \\
\hline & - & 40 & 8 & [\%] Capacity factor \\
\hline & - & 35 & 45 & [yr] Lifespan \\
\hline & - & 76 & 76 & {$[\mathrm{~g} / \mathrm{MJ}]$ Direct emission of $\mathrm{CO}_{2}$} \\
\hline & - & 829 & 829 & {$[\mathrm{mg} / \mathrm{MJ}]$ Direct emission of $\mathrm{NO}_{\mathrm{x}}$} \\
\hline & - & 192 & 192 & {$[\mathrm{mg} / \mathrm{MJ}]$ Direct emission of $\mathrm{SO}_{2}$} \\
\hline \multirow{5}{*}{$\begin{array}{l}\text { Diesel } \\
\text { contribution, } \\
\text { transport and } \\
\text { heating value }\end{array}$} & - & 45 & 43 & [\%] Chile's diesel share to diesel mix (national refineries) \\
\hline & - & 55 & 57 & [\%] USA diesel share to diesel mix \\
\hline & - & 45.6 & 45.6 & {$[\mathrm{MJ} / \mathrm{kg}]$ Higher heating value of diesel } \\
\hline & - & 664 & 664 & {$[\mathrm{~km}]$ Distance between refinery and oil power plant in road } \\
\hline & - & 18,838 & 8785 & [km] Average distance from diesel exporting countries \\
\hline \multirow{4}{*}{$\begin{array}{l}\text { Crude oil } \\
\text { contribution } \\
\text { and transport }\end{array}$} & - & $84 \%$ & $84 \%$ & [\%] Latin American crude oil share to crude oil mix \\
\hline & - & $16 \%$ & $16 \%$ & [\%] UK crude oil share to crude oil mix \\
\hline & - & 5204 & 5204 & [km] Weighted average distance of crude oil from Latin American countries \\
\hline & - & 11,112 & 11,112 & {$[\mathrm{~km}]$ Distance for crude oil transport from UK } \\
\hline
\end{tabular}

${ }^{\mathrm{a}}$ Parameters in bold vary through the years. 
Table S6. Life cycle inventory for biogas, biomass, solar PV, wind and hydropower in 2004, 2009 and 2014 ${ }^{\mathrm{a}}$ [1-4].

\begin{tabular}{|c|c|c|c|c|}
\hline & 2004 & 2009 & 2014 & Description \\
\hline \multicolumn{5}{|l|}{ Biogas } \\
\hline \multirow{4}{*}{$\begin{array}{l}\text { Cogen-gas } \\
\text { engine }\end{array}$} & - & - & 1000 & {$\left[\mathrm{~kW}_{\mathrm{e}}\right]$ capacity average of biogas engine } \\
\hline & - & - & 77 & [\%] Capacity factor of electricity from biogas \\
\hline & - & - & 20 & [yr] Life time of biogas engine \\
\hline & - & - & 0.33 & Scaling factor. Estimated from original size and actual size to the 0.6 power \\
\hline \multirow{2}{*}{$\begin{array}{l}\text { Biogas } \\
\text { contribution }\end{array}$} & - & - & 0 & [\%] biogas contribution to biogas mix from landfill ( $85 \%$, assumed zero burdens) \\
\hline & - & - & 15 & [\%] biogas contribution to biogas mix from sewage sludge plants \\
\hline \multicolumn{5}{|l|}{ Biomass } \\
\hline \multirow[t]{5}{*}{ CHP plant } & 10 & 10 & 10 & {$\left[\mathrm{MW}_{\mathrm{e}}\right]$ Average capacity of actual plant of biomass } \\
\hline & 63 & 63 & 63 & [\%] Capacity factor of electricity from biomass \\
\hline & 20 & 20 & 20 & [yr] Life time of biomass boiler \\
\hline & 80 & 80 & 80 & [yr] Life time of biomass building \\
\hline & 0.18 & 0.18 & 0.18 & Scaling factor. Estimated from original size and actual size to the power of 0.6 \\
\hline \multirow{4}{*}{$\begin{array}{l}\text { Biomass } \\
\text { contribution } \\
\text { and transport }\end{array}$} & 20 & 20 & 20 & {$[\mathrm{~km}]$ average distance travelled by truck of industrial residual wood } \\
\hline & - & - & 50 & {$[\mathrm{~km}]$ average distance travelled by truck of agricultural crops residues } \\
\hline & 100 & 100 & 90 & [\%] Industrial residual wood contribution to the mix \\
\hline & 0 & 0 & 0 & [\%] Crops residues contribution to the $\operatorname{mix}(2014: 10 \%$, assumed zero burdens) \\
\hline \multicolumn{5}{|r|}{ 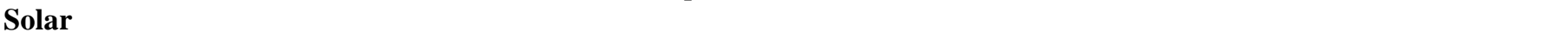 } \\
\hline \multirow[t]{3}{*}{ PV plant } & - & - & 24 & [\%] Capacity factor \\
\hline & - & - & 0.7 & [\%] Rated power degradation per year \\
\hline & - & - & 30 & [yr] Lifespan \\
\hline \multicolumn{5}{|l|}{ Wind } \\
\hline \multirow[t]{4}{*}{ Onshore } & - & - & 2000 & {$\left[\mathrm{~kW}_{\mathrm{e}}\right]$ Capacity average of each turbine in the wind farm } \\
\hline & - & - & 27 & {$[\%]$ Capacity factor } \\
\hline & - & - & 40 & [yr] Lifespan of wind turbine fixed part \\
\hline & - & - & 20 & [yr] Lifespan of wind turbine moving part \\
\hline \multicolumn{5}{|l|}{ Hydropower } \\
\hline \multirow{2}{*}{$\begin{array}{l}\text { Technology } \\
\text { contribution }\end{array}$} & 58 & 59 & 56 & [\%] electricity from reservoirs share of total electricity from hydropower \\
\hline & 42 & 41 & 44 & [\%] electricity from run-of river share of total electricity from hydropower \\
\hline \multirow[t]{5}{*}{ Reservoir } & 373 & 373 & 373 & {$\left[\mathrm{MW}_{\mathrm{e}}\right]$ Average capacity of reservoirs } \\
\hline & 40 & 48 & 43 & [\%] Capacity factor of reservoirs \\
\hline & 14 & 14 & 14 & {$[\mathrm{mg} / \mathrm{kWh}] \mathrm{CH}_{4}$ emission factor } \\
\hline & 100 & 100 & 100 & [yr] Lifespan of reservoirs \\
\hline & 0.44 & 0.44 & 0.44 & Scaling factor. Estimated from original size and actual size to the power of 0.6 \\
\hline \multirow[t]{4}{*}{ Run-of-river } & 28.7 & 28.7 & 28.7 & {$\left[\mathrm{MW}_{\mathrm{e}}\right]$ average capacity of run-of river } \\
\hline & $64 \%$ & $68 \%$ & $60 \%$ & [\%] Capacity factor of run-of river \\
\hline & 80 & 80 & 80 & [yr] Lifespan of run-of river \\
\hline & 0.49 & 0.49 & 0.49 & Scaling factor. Estimated from original size and actual size to the power of 0.6 \\
\hline
\end{tabular}

${ }^{\mathrm{a}}$ Parameters in bold vary through the years. 


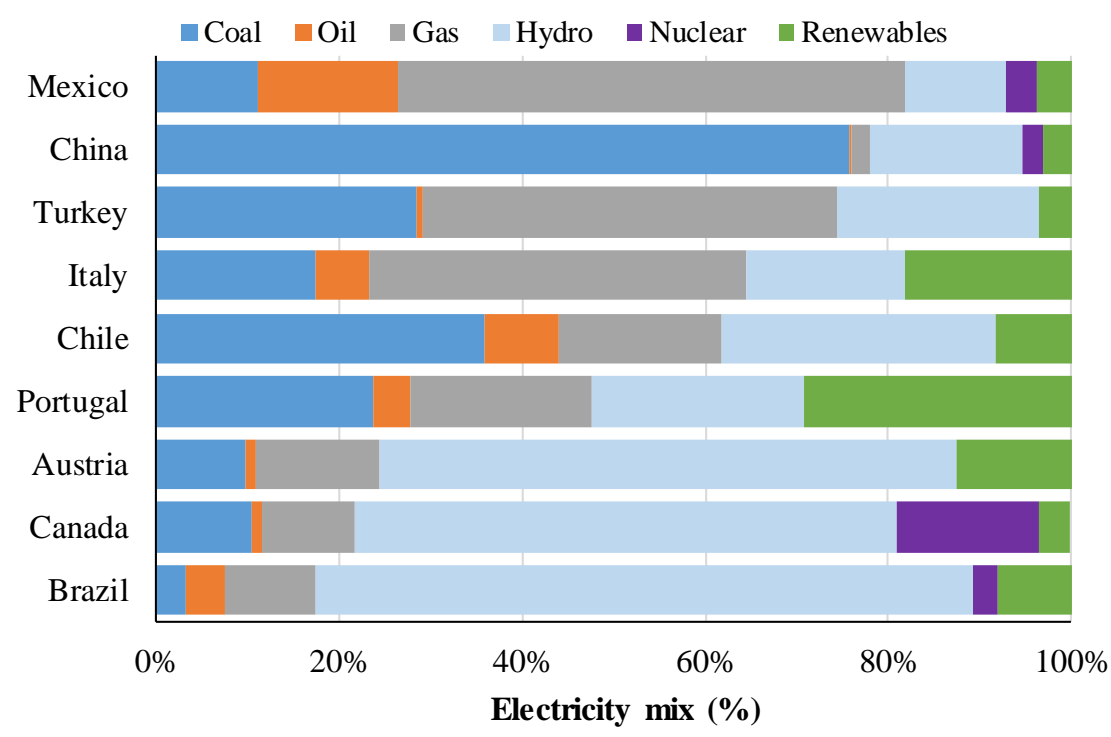

Figure S1. Electricity mix of selected countries in comparison with Chile (Average technology contribution between 2011 and 2014 [5])

\section{References:}

1. Centro de Despacho Económico de Carga. (2016). Updated database. Sistema Eléctrico Nacional. Retrieved May 5, 2016, from https://www.coordinador.cl/informes-y-documentos/

2. Comisión Nacional de Energía. (2015). Installed capacity in the SIC and SING.

3. Comisión Nacional de Energía de Chile. (2015). Database of electricity generation in Chile. Retrieved May 5, 2015, from https://www.cne.cl/estadisticas/electricidad/

4. Superintendencia del Medioambiente de Chile (SMA). (2015). Data record of emissions and fuel composition for Chilean thermal power plants. Santiago, Chile.

5. The World Bank. (2015). Electricity production indicators. Retrieved October 29, 2016, from https://data.worldbank.org/. 